\title{
The Alegre Lineament and its role over the tectonic evolution of the Campos Basin and adjacent continental margin, Southeastern Brazil
}

\author{
Salomão Silva Calegari a, *, Mirna Aparecida Neves ${ }^{\text {b }}$, Felipe Guadagnin ${ }^{\text {c }}$, \\ George Sand França ${ }^{\mathrm{d}}$, Maria Gabriela Castillo Vincentelli ${ }^{\mathrm{e}}$ \\ a Programa de Pós-Graduação em Geologia, Universidade de Brasília, Brasília, Brazil \\ b Departamento de Geologia, Universidade Federal do Espírito Santo, Alegre, Brazil \\ ' Campus Caçapava do Sul, Universidade Federal do Pampa, Caçapava do Sul, Brazil \\ d Observatório Sismológico, Universidade de Brasília, Brasília, Brazil \\ e Laboratório de Integração de dados Sísmicos e Geológicos, Universidade Estadual Paulista, Rio Claro, Brazil
}

\section{A R T I C L E I N F O}

\section{Article history:}

Received 29 July 2015

Received in revised form

9 March 2016

Accepted 14 April 2016

Available online 16 April 2016

\section{Keywords:}

Brittle structures

Reactivation

Alegre Lineament

\begin{abstract}
A B S T R A C T
The structural framework and tectonic evolution of the sedimentary basins along the eastern margin of the South American continent are closely associated with the tectonic framework and crustal heterogeneities inherited from the Precambrian basement. However, the role of NW-SE and NNW-SSE structures observed at the outcropping basement in Southeastern Brazil and its impact over the development of those basins have not been closely investigated. In the continental region adjacent to the Campos Basin, we described a geological feature with NNW-SSE orientation, named in this paper as the Alegre Fracture Zone (AFZ), which is observed in the onshore basement and can be projected to the offshore basin. The main goal of this work was to study this structural lineament and its influence on the tectonic evolution of the central portion of the Campos Basin and adjacent mainland. The onshore area was investigated through remote sensing data joint with field observations, and the offshore area was studied through the interpretation of 2-D seismic data calibrated by geophysical well logs. We concluded that the AFZ occurs in both onshore and offshore as a brittle deformation zone formed by multiple sets of fractures that originated in the Cambrian and were reactivated mainly as normal faults during the rift phase and in the Cenozoic. In the Campos Basin, the AFZ delimitates the western side of the CorvinaParati Low, composing a complex fault system with the NE-SW faults and the NW-SE transfer faults.
\end{abstract}

(c) 2016 Elsevier Ltd. All rights reserved.

\section{Introduction}

During the evolution of rift-drift sedimentary basins, the geological and structural heterogeneities of the basement usually determine the tectonic evolution of the basins, controlling the location of its main depocenters, its subsidence rates and its tectonic and sedimentary evolution (Michon and Sokoutis, 2005; Wilson, 2005; Wilson et al., 2006).

The development of the basins along the eastern margin of the South American continent are closely linked to the structural framework and crustal heterogeneities inherited from the crystalline basement (e.g., Schaller, 1973; Ponte and Asmus, 1978; Dias et al., 1987; Guardado et al., 1989; Davison, 1997; Fetter, 2009).

\footnotetext{
* Corresponding author.

E-mail address: salomaocalegari@hotmail.com (S.S. Calegari).
}

The work of Bezerra and Vita-Finzi (2000) and Bezerra et al. (2014) in NE Brazil demonstrates an important influence of the Precambrian shear zones reactivations on the sedimentation and topographic pattern of the continental margin up to the Quaternary. However, whereas the basement fabric in NE Brazil is orthogonal to the coast and can be easily traced from the onshore to the offshore part of the margin (e.g., Bezerra et al., 2014), in SE Brazil the basement fabric is parallel to the coast.

Nevertheless, it is already known that in the SE Brazilian margin, the Neoproterozoic foliation oriented to NE-SW and NNE-SSW, even being parallel to the coast, does control the geometry of the coastal basins (Ojeda, 1982; Chang et al., 1992). Here, the main and recent question is about the role of the NW-SE and NNW-SSE structures, which probably worked together with the NE-SW arrangement in the configuration of the basins. Some authors (e.g., Novais et al., 2004; Fetter, 2009) affirm that NNW-SSE structures represented by the Colatina Lineament, in Northern of the 
Espírito Santo State, influenced the tectonic evolution of the Campos and Espírito Santo basins. Fetter (2009) considers that NNWSSE and NE-SW Proterozoic structures are responsible for the control of the main Campos Basins's depocenter, defining basement highs during the rift phase. The author shows a NNW-SSE structural trend as the prolongation of the Colatina Lineament that is projected from mainland to offshore, together with another lineament positioned farther south. The study of this unknown geological feature, parallel to the Colatina Lineament, is the aim of this work.

Located in the Southern part of the state of Espírito Santo, this NNW-SSE lineament is a well-marked trace viewed through remote sensing images, which we named here the Alegre Lineament. The Alegre Lineament runs through the entire southern region of the state and its projection into the offshore area reaches major oil fields, such as Enchova and Bonito (Fig. 1). On the seabed, the NNWSSE path of this linear feature is absent, but if one consider the line projection from the land up to the ocean, it will be noted the parallelism of the trace with an inflection of the oceanic slope towards the NNW-SSE direction. This inflection is coincident with the projection of the Colatina Lineament to the offshore area (Figs. 1 and 3), raising the possibility that the Alegre Lineament can also be prolonged to offshore, where it could act in the structural control of the offshore basin.

In this paper, we used remote sensing, surveying data, seismic and well data interpretation to show that this feature corresponds to a geological structure that outcrops onshore and extends to offshore up to the Campos Basin. Furthermore, we proposed that this structure acted in both, offshore and onshore, as a set of fractures originated in the Cambrian, which reactivated as normal faults during the breakup of the supercontinent Pangea and during the Cenozoic.

\section{Geological and structural context}

\subsection{General features of the Campos Basin and its crystalline basement}

The crystalline basement of the study area consists mainly of Precambrian rocks (Fig. 1), including highly deformed orthogneiss and paragneiss of Paleo- and Neoproterozoic age, besides Neoproterozoic to Cambrian granitoids (Silva et al., 2004; PedrosaSoares et al., 2007; De Campos, 2014). Siliciclastic Miocene sediments of the Barreiras Formation cover partially the basement along the coast (Rossetti et al., 2013), in addition to quaternary alluvial, colluvial, fluvial and coastal deposits (Silva et al., 2004).

Due to its Precambrian structural evolution, the area is well marked by the shear zones of the Late Brasiliano/Pan-African Cycle. These features are NE-SW to N-S straight bands where mylonitic foliation occurs due to dextral and obliquely convergent movements (Alkmim et al., 2006; Cunningham et al., 1998). However, the origin and constitution of the NW-SE and NNW-SSE structures of this continental area are not yet established. Silva et al. (2004) and Vieira et al. (2014) ascribe the NW-SE oriented structures to sinistral shear zones, or to faults and fractures. The Colatina Lineament (Fig. 1) is represented, in map, as a network of NNW-SSE oriented fractures (Vieira et al., 2014), and some authors (Valente et al., 2009; Novais et al., 2004) discuss the relationship between the dikes that occur along this Lineament and the Cretaceous basalts (Cabiunas Formation) of the Campos Basin. Despite the absence of studies about the Alegre Lineament, segments of this feature were drawn in some geological maps (Silva, 1993; Vieira, 1997; Vieira et al., 2014), but correlations with outcropping structures were not shown.

The oceanic portion of the crystalline basement is under the sedimentary sequences of the Campos Basin, the main oil producer in Brazil (Guardado et al., 2000). This coastal basin covers an area of about $100,000 \mathrm{~km}^{2}$, from which only $500 \mathrm{~km}^{2}$ are emerged (Mohriak et al., 1990). The geological feature known as Vitória High borders the Campos Basin to the north, separating it from the Espírito Santo Basin, while the Cabo Frio High is the southern divisor, separating it from the Santos Basin (Fig. 1; Schaller, 1973; Guardado et al., 2000). Geological records of the Campos Basin show three main depositional environments, with a non-marine clastic sequence, an evaporite sequence and a frankly marine paralic clastic sequence (Ponte and Asmus, 1978).

\subsection{Tectonic and structural evolution of the onshore area}

The study area is located at the transition between the Araçuaí and Ribeira Mobile Belts, both components of the Mantiqueira Province (Almeida et al., 1981). The boundary between the Ribeira and Araçuaí Belts occurs close to the $21^{\circ}$ parallel south (PedrosaSoares and Wiedemann-Leonardos, 2000), where the foliation strike inflects from NE-SW (Ribeira Belt) to NNE-SSW and N-S (Araçuaí Belt) (Pedrosa-Soares et al., 2001).

The Mantiqueira Province originated from the continental collision of the Brasiliano/Pan-African orogeny that occurred between the Neoproterozoic and Early Paleozoic (Almeida et al., 1981; Heilbron et al., 2000). The Brasiliano/Pan-African orogeny involved subduction of an oceanic lithosphere and the closure of an oceanic basin, with intense tectonism, high-grade metamorphism and granitic magmatism (c. $625 \mathrm{Ma}$ to $570 \mathrm{Ma}$; Pedrosa Soares et al., 2001). Dextral-transpressive shear zones, such as the Guaçuí, Batatal and Além Paraíba (Fig. 1), formed in the final phase of this orogeny, probably in the interval between 560 and $535 \mathrm{Ma}$ (Alkmim et al., 2006). Their origin is considered the consequence of a lateral escape to the south after the propagation of the thrust fronts. The last magmatic and deformational manifestations of this orogeny occurred between 530 and 480 Ma (Pedrosa Soares et al., 2011; De Campos et al., 2004; De Campos, 2014; Gradim et al., 2014), with the establishment of the West Gondwana Supercontinent. After the assemblage of the supercontinent Gondwana, further accretion throughout the Paleozoic and Mesozoic led to the formation of Pangaea. Details about the geological evolution of the Ribeira and Araçuí Belts can be found at Trompette et al. (1993); Pedrosa-Soares et al. (2001), (2007), (2011); Pedrosa-Soares and WiedemannLeonardos (2000); Wiedemann et al. (2002); De Campos et al. (2004); De Campos (2014); Heilbron et al. (2000), (2004), (2013); Alkmim et al. (2006), (2007); and Gradim et al. (2014).

The fragmentation of Pangaea, initiated in the Mesozoic, defines the configuration of today's continents and oceans (e.g., Brito Neves, 2002; Veevers, 2004; Stampfli et al., 2013; Torsvik and Coock, 2013). The extensional events related to this continental rearrangement shaped the broad outlines of the continental margin of the SE Brazil. After a phase of thermal anomaly during the Jurassic, the rift phase took place in the Early Cretaceous, imposing to this region an extensional regime with NW-SE (Chang et al., 1992) to WNW-ESE orientation between 137 and 122 Ma (Stanton et al., 2010).

By the end of the Paleocene and the end of the Oligocene, a NWSE to NNW-SSE-oriented extensional stress acted in SE Brazil (Hiruma et al., 2010), giving rise to the Continental Rift of Southeastern Brazil (CRSB; Riccomini et al., 1989). Continental sedimentary basins, elongated in the NE-SW direction, occur along the CRSB, such as the São Paulo, Taubate and Resende Basins in the states of São Paulo and Rio de Janeiro (Riccomini et al., 1989; Almeida and Carneiro, 1998). In the Paleogene sequence of the Taubaté Basin, Cogné et al. (2013) relate a transtensional state of stress with the greatest horizontal stress trending NE-SW, which is in agreement with the proposed by Salomon et al. (2015) to a 


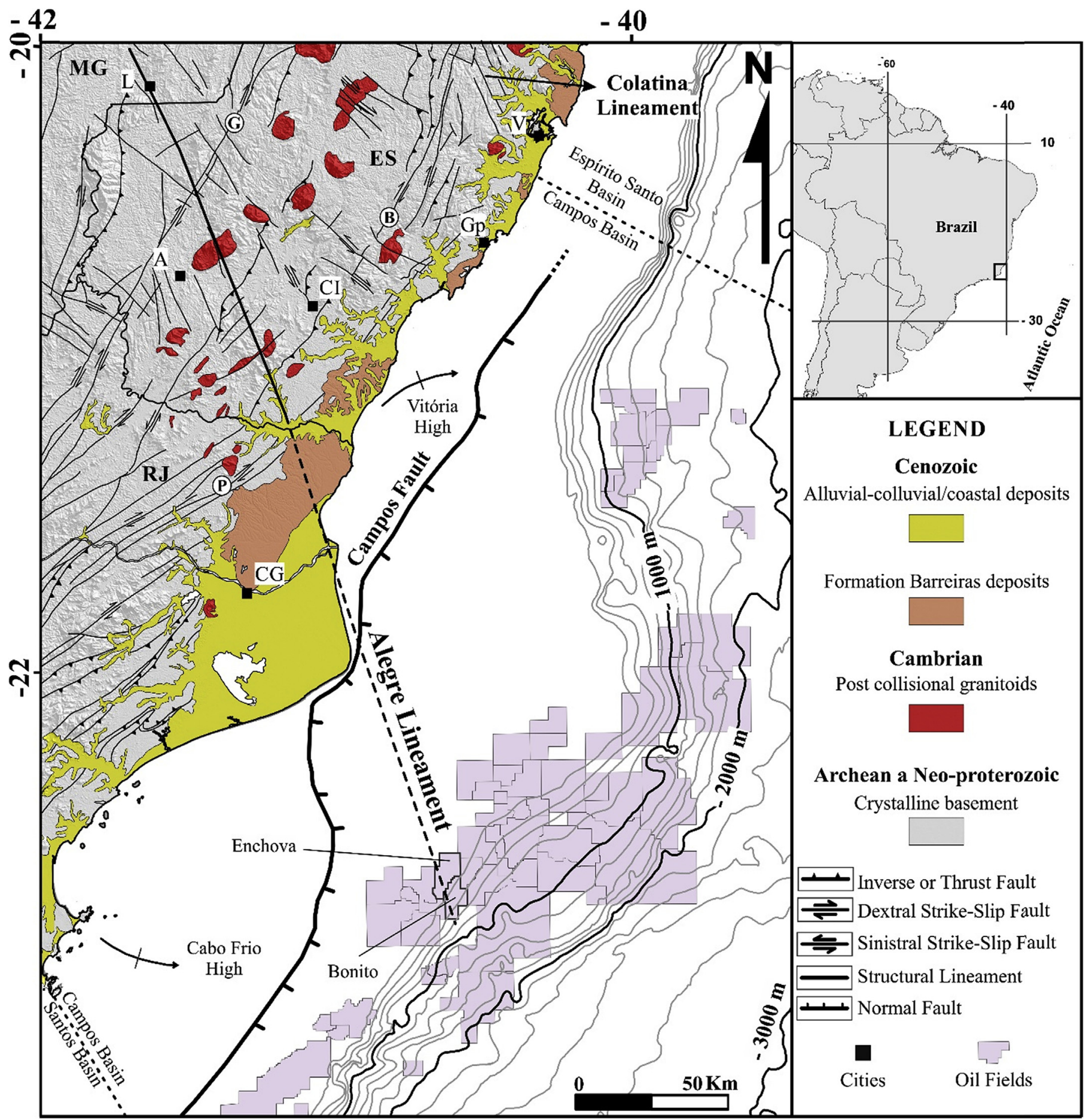

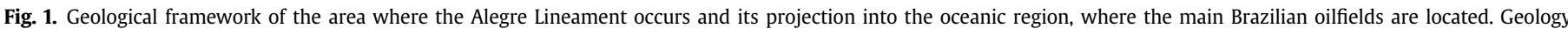

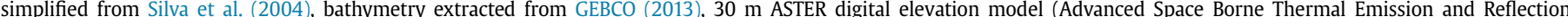

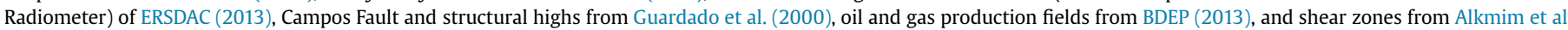

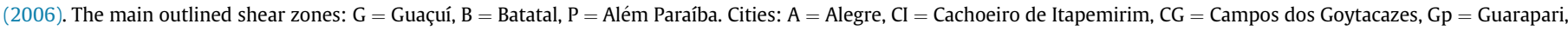
$\mathrm{L}=$ Lajinha, $\mathrm{V}=$ Vitória. States: $\mathrm{ES}=$ Espírito Santo, $\mathrm{RJ}=$ Rio de Janeiro, $\mathrm{MG}=$ Minas Gerais.

farther south area.

For the Neogene and younger times, many controversies remain about the existence of one or more effort arrangements in the SE Brazilian margin. Some authors propose an E-W sinistral strike-slip (Riccomini et al., 1989; Salvador and Riccomini, 1995; Silva and Mello, 2011) and others a transpressional tensor, with the greatest principal axis close to E-W (Cogné et al., 2013; Salomon et al., 2015). For Zalán and Oliveira (2005), the sinistral strike-slip with the minor axis oriented to NW-SE comes from the Paleogene up to the Neogene. Younger events would be an E-W dextral transcurrence acting in the Pleistocene, followed by an extensional NW-SE event in the Holocene (Riccomini et al., 1989; Salvador and 


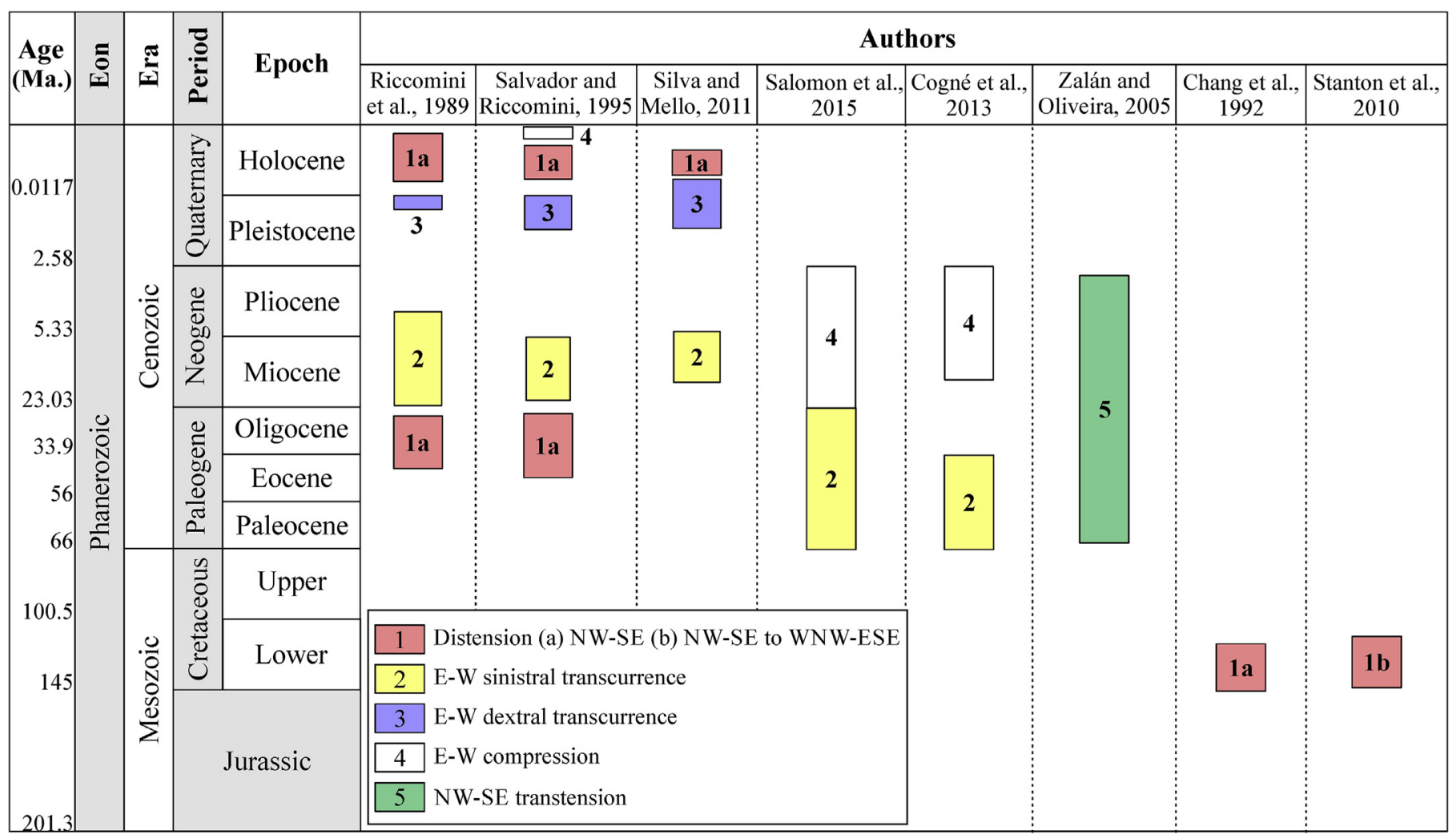

Fig. 2. Schematic arrangement with the tectonic events proposed by some authors for SE Brazil.

Riccomini et al., 1995).

Fig. 2 summarize the main tectonic phases proposed by the authors cited here for times from the Early Cretaceous up to the Holocene.

The cause of these variations is still an unresolved issue. Some authors argue that the subduction of the Nazca Plate beneath the South American Plate's western side influences the tectonic evolution of the SE Brazilian margin (e.g. Salomon et al., 2015; Cogné et al., 2013; Cobbold et al., 2001, 2007), generating a plate-wide compressional stress (Cogné et al., 2012). Another line thinking consider the westward rotation of the South American Plate about an Euler pole (e.g. Hasui, 1990; Thomaz Filho et al., 2005) located in NE Brazil (Szatmari, 2012) as the generator of tectonic effort over this intraplate region. By the other hand, Zalán and Oliveira (2005) affirm that the state of stress imposed to the continental margin of SE Brazil in Cenozoic times is due to a gravitational collapse that followed the crustal uplifting caused by the passing of the plate over the Trindade Plume. The remoteness of this area of the heated region would be the responsible for a slightly oblique NW-SE distension that imposed a sinistral transtension from 58 to $20 \mathrm{Ma}$.

The comparison between the Brazilian continental margin and its African counterpart does not solve the question. In the west continental margin of South Africa, Viola et al. (2012) establish a dozen deformational phases from the Precambrian up to nowadays. In the Cenozoic, they found a NW-SE distensional event (after 54 $\mathrm{Ma}$ ) that was replaced by a NW-SE compression in present days. Nevertheless, Salomon et al. (2015) affirm that the evolution of stress regimes was significantly different in South American and African margins, the first one subjected to compressional stresses (resulting in strike-slip regimes with NE-SW to ENE-WSW compressional axis), and the second one subjected to extensional rifting and flexural bending since the Paleogene.

Finally, an important fact that marked the onshore geological evolution of our study area was the crustal uplifting. Several authors relate an important uplift process of the Brazilian continental margin during and after the Late Cretaceous (eg. Hackspacher et al., 2004; Hiruma et al., 2010; Karl et al., 2013). Cogné et al. (2012) propose an episodic post-rift uplifting, with three accelerated periods of crustal cooling; the first one in the Late Cretaceous, the other one in the Paleogene and the third in the Neogene. This last uplift phase would be accompanied by reactivations of inherited structures, erosion and renewing of the landscape. Jelinek et al. (2014) go further, relating four denudation and cooling episodes since the Permian/Eo Jurassic. According to these authors, a Late Cretaceous-Paleogene denudation occurred in the Mantiqueira Range (that includes part of the study area) possibly due to a thermal-isostatic uplift and magmatic underplating, followed by a Neogene denudation that would be provoked by a more erosive semi-arid climate.

\subsection{Tectonic and structural evolution of the offshore area- Campos Basin}

Lithospheric extensional mechanisms that led to the breakup of the paleocontinent Gondwana and the formation of the South Atlantic Ocean originated the Campos Basin (Milani et al., 2000). Its tectono-stratigraphic evolution, similarly to that of the basins along the continental margin of Southeastern Brazil, is divided into four main phases: pre-rift, rift, transitional and drift (e.g., Cainelli and Mohriak, 1999; Ojeda, 1982).

The pre-rift phase represents the intracratonic stage of the supercontinent Pangea, marked by high rates of crustal uplift and the formation of large peripheral depressions (Cainelli and Mohriak, 1999; Ojeda, 1982). The first lava flows of tholeiitic basalts of the Cabiúnas Formation occurred during this stage (Mohriak, 2012).

The rift phase is associated with intense tectonic activity 


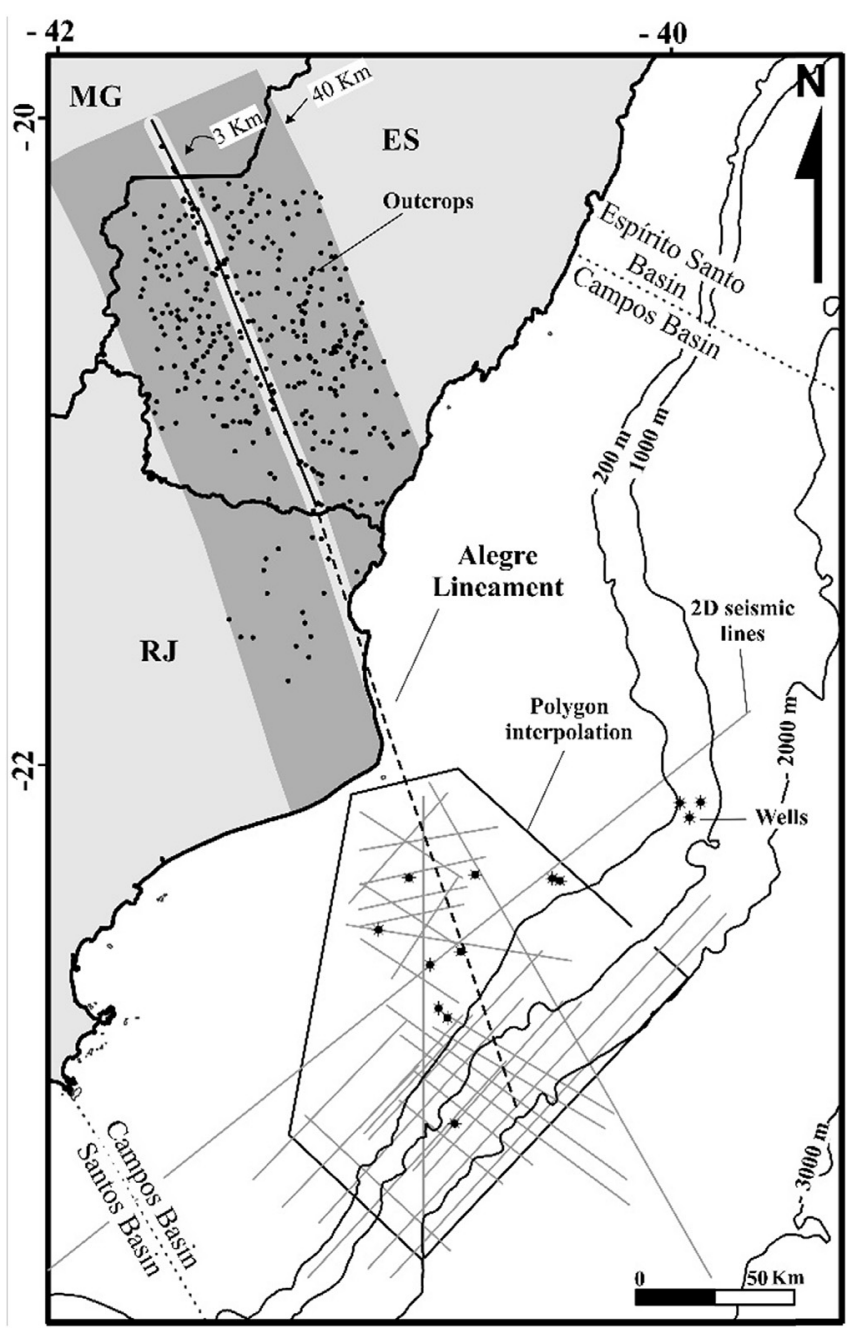

Fig. 3. Location of studied outcrops in the continental area and interpolation area in Campos Basin, showing seismic lines and wells. ES = Espírito Santo State, RJ = Rio de Janeiro State, MG = Minas Gerais State.

resulting from normal fault stresses in the Early Cretaceous, which produced a system of elongated NE-SW oriented rift valleys subparallel to the main structures of the adjacent Precambrian basement. This phase developed horsts, grabens and half-grabens delimited mainly by synthetic faults with the same orientation (Dias et al., 1987, 1990). NNW-SSE and E-W striking faults are not so pronounced, but sometimes they control depocenters of the sedimentary basin formed during the rift phase (Dias et al., 1990). The Campos Fault or Cretaceous Hingeline is an important normal fault originated in this phase. This regional structure is approximately parallel to the present-day shoreline and dips towards the basin's main depocenter, separating Cretaceous sedimentary units from the shallow basement (Fig. 1; Dias et al., 1990; Guardado et al., 1989). The framework of the Proterozoic basement influenced the main depocenters of the basin during the rift phase, defining tectonic blocks delimited by NE-SW and NNW-SSE structures (Fetter, 2009). Cobbold et al. (2001) and Meisling et al. (2001) described a set of NW-SE transfer zones that obliquely segmented the Brazilian Southeast passive margin in the Early Cretaceous. These structures controlled variations in the dip of tectonic blocks and the most important accumulation zones of Barremian lacustrine sediments, which formed the main hydrocarbon generating rocks of the Campos Basin (Guardado et al., 2000).
The Neocomian volcanism (Mizusaki et al., 1988), which represent the climax of basaltic lava extrusion from the Cabiunas Formation (Winter et al., 2007), occurred in the rift phase with ages between 112 and 133 Ma (Fodor et al., 1983; Renne et al., 1992). Barremian sediments were deposited soon after, composed by proximal conglomerates and sandstones (Itabapoana Formation), fluvial-lacustrine pelites (Atafona Formation), shales and coquinas (Coqueiros Formation), corresponding to the lower part of the Lagoa Feia Group (Winter et al., 2007; Rangel et al., 1994).

The transitional stage represents the early phase of thermal subsidence, marked by the suspension of lithospheric stretching and rifting of the continental crust (Cainelli and Mohriak, 1999). The sedimentary units are mainly composed by conglomerates and sandstones deposited near fault scarps (Itabapoana Formation) and shallow platform carbonates, marl and sandstone (Gargaú and Macabu Formation) covered by evaporites (Retiro Formation) in the upper part of the Lagoa Feia Group (Winter et al., 2007).

The drift phase is characterized by minor regional unconformities and increased thermal subsidence (Ojeda, 1982). Two main marine sequences occur at this stage: one transgressive and other regressive. The marine transgressive phase (Albian-Late Cretaceous) is characterized by the shallow water carbonates of the Macaé Group, with sandy (Goitacás Formation) and calcarenite facies (Quissamã Formation), which gradate to a sequence of marl and shale (Outeiro Formation; Dias et al., 1990; Mohriak, 2003; Winter et al., 2007). The Tamoios Member (Ubatuba Formation) corresponds to basin shales that mark the end of the marine transgression (Rangel et al., 1994). The marine regression occurred from the Late Cretaceous to the Neogene Period, with the

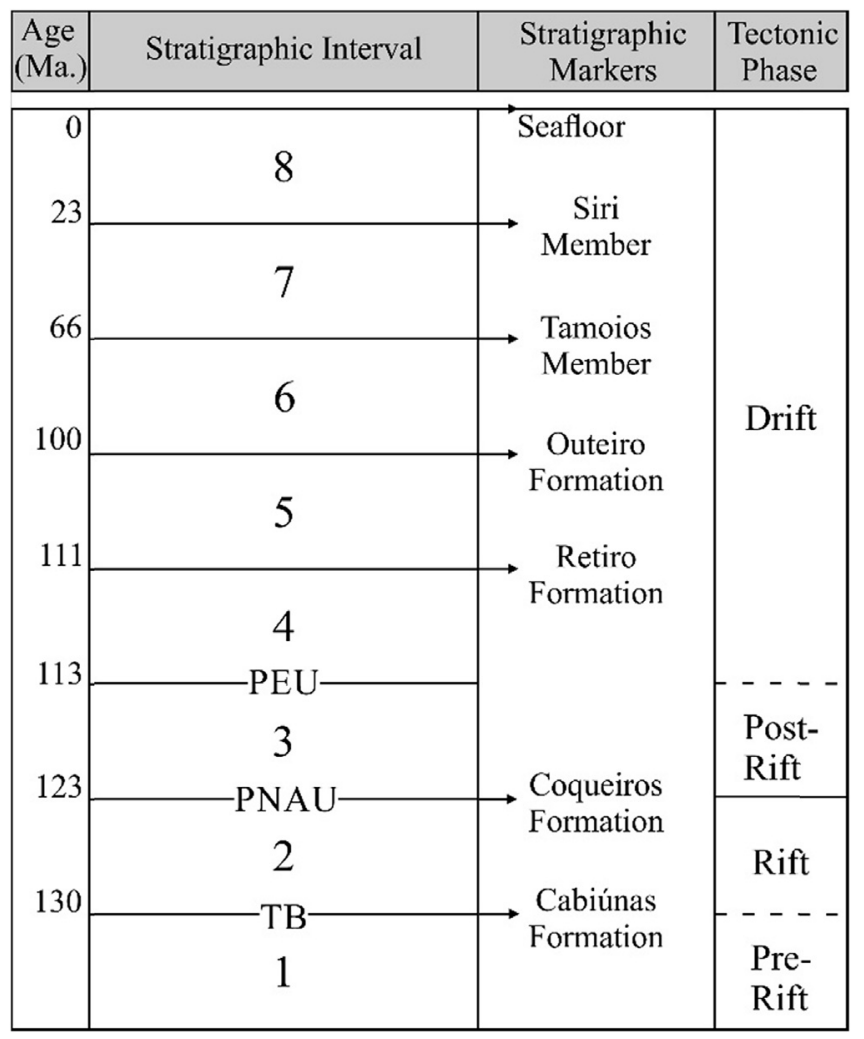

Fig. 4. Illustration of stratigraphic markers used to define the age of seismic horizons (simplified from Winter et al., 2007). Stratigraphic sequences: 1 = Basement, 2 = Rift $3=$ Post-Rift, $4=$ Salt, 5 = Albian, $6=$ Cenomanian-Maastrichtian, $7=$ PaleoceneOligocene, $8=$ Miocene-Pleistocene, TB $=$ Top of basalts, PNAU = Pre-Neo-Alagoas Unconformity, PEU = Pre-Evaporite Unconformity. 
deposition of siliciclastic sediments of the Campos Group, composed by continental shelf sandstones (São Tomé Member), continental shelf carbonates (Grussaí Member), and calcirudites and calcarenites (Siri Member), which make up the Emborê Formation (Mohriak, 2003; Winter et al., 2007). Basin pelites of the Ubatuba Formation (Geribá Member) and sandy turbidite deposits (Caraepebus Formation) complete the marine sequence of the Campos Group (Winter et al., 2007).

The first record of salt tectonics occurs in the Lower to Middle Albian transition, caused by sediment overload and tilting of the basin, resulting in the formation of salt domes and listric faults (Dias et al., 1990; Mohriak et al., 1990). A new phase of halokinetic movement occurred in the Neoalbian, evolving into the formation of growth faults (Dias et al., 1990). The interval between the Late Cretaceous and the Paleocene corresponds to the passive margin period, with continuous subsidence processes and possible residual salt movements (Dias et al., 1990; Mohriak et al., 1990; Cainelli and Mohriak, 1999). The normal faults of the Campos Basin related to salt tectonics generally present a synthetic geometry (Mohriak, 2003). Guardado et al. (1989) point
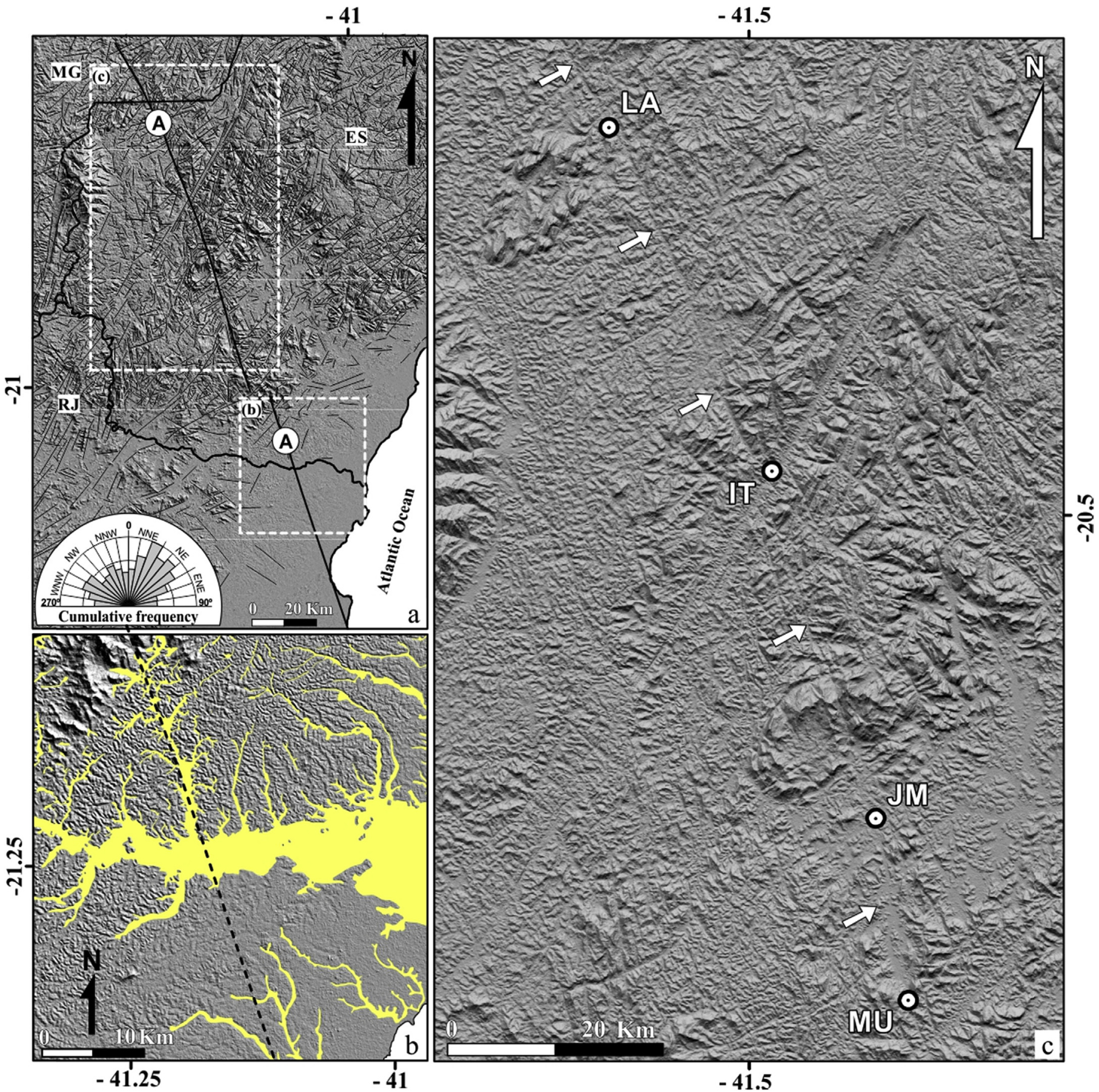

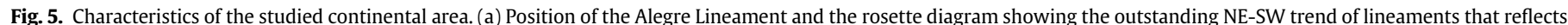

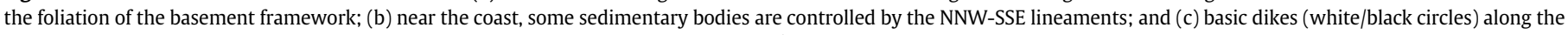
Alegre Lineament (indicated by white arrows). Dikes: LA = Lajinha, IT = Itaici, JM = Jerônimo Monteiro, $\mathrm{MU}=\mathrm{Muqui}$. 
out that these faults were reactivated from the Albian to the Holocene, playing an important role in the control of sedimentation and the formation of traps in the main hydrocarbon accumulations of the Campos Basin.

\section{Material and methods}

The study area is delimited by a polygon drawn around the Alegre Lineament. The continental portion covers a small area in the extreme southeast of the state of Minas Gerais, the entire southern portion of the state of Espírito Santo, and part of the northern region of the state of Rio de Janeiro, whereas the marine portion extends into the central Campos Basin (Fig. 3). The structural analysis involved surface observations through remote sensing data and the acquisition of structural data in the field, and subsurface investigations based on analysis of seismic reflection profiles, in addition to correlation with geophysical well logs.

The remote sensing analysis involved the integration of the $30 \mathrm{~m}$ ASTER digital elevation models (ERSDAC, 2013) and orthophotos (IEMA, 2007) in a GIS environment. We outlined the lineaments manually over the ASTER image by identifying relief-aligned features, mainly enclosed valleys. The lighting orientation was changed in the software aiming to contrast different line directions and, posteriorly, the distortions of location in lines were corrected, one by one, using an orto-photo as control. Two interpreters repeated such procedure and only the lines viewed by both were considered, in order to minimize misinterpretations.

The field survey included the geometric and kinematic analysis of joints, faults, striations and foliations, in order to correlate the field structures with those observed by remote sensing, as well as cross-cutting relationships between structures. The database of field structures includes 385 outcrops, with 322 foliation data, 1629 joints and 44 fault planes with striae. The foliations and joint measures were grouped into two sets; the first one included all outcrops located at a distance of $0-40 \mathrm{~km}$ from the path of the Alegre Lineament ( $40 \mathrm{~km}$ buffer), and the second included the outcrops within $0-3 \mathrm{~km}$ (3 km buffer; Fig. 3). The purpose of this division was to search what kind of geological structures acts in the area influenced by the Alegre Lineament and to compare it with the regional background. The field structural data were statistically treated using low hemisphere stereographic projections on a grid of equal area, through the OpenStereo software (Grohmann et al., 2011). The fault data were treated separately in four areas or domains for paleotension analysis. The tectonic stress tensor was performed by the inversion of kinematic fault data by Rotational Optimization method using WinTensor v. 5.05 program (Delvaux and Sperner, 2003).

The subsurface was analyzed through the structural

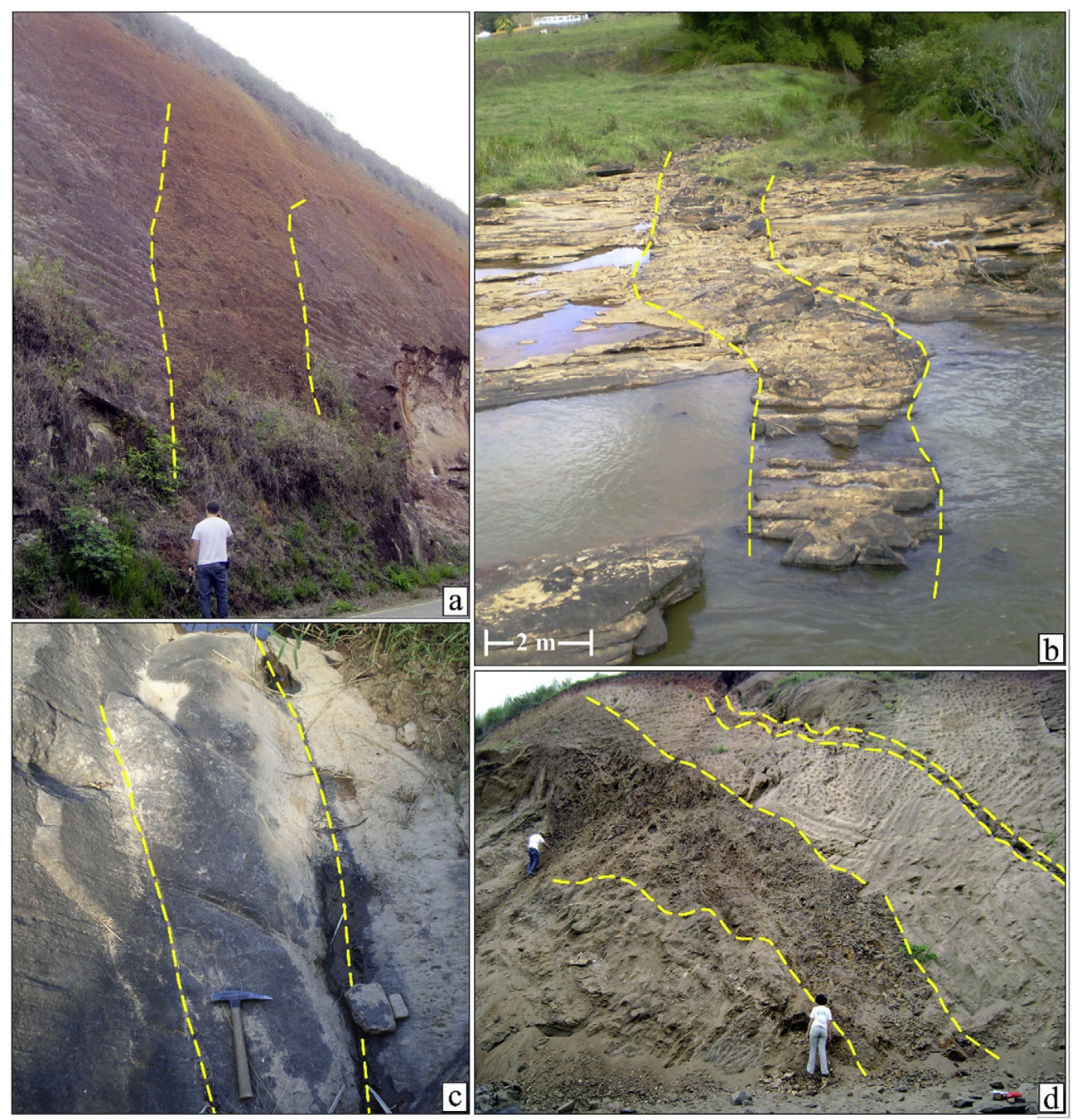

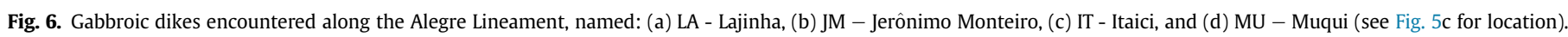


interpretation of $312 \mathrm{D}$ seismic lines $(3051.544 \mathrm{~km})$ and 13 oil wells, whose data were provided by the National Petroleum Agency (ANP; Fig. 3). The litho- and chronostratigraphic information obtained from the wells, such as unconformities and boundaries between formations (stratigraphy markers; Fig. 3), together with geophysical well logs (gamma ray, sonic and density) were used to define the ages of seismic reflectors and the lateral correlation between the lines. The wells (in depth) were linked to seismic lines (in time), using the interval velocity recorded in the sonic profiles in microseconds per foot (ms/feet) for each well. Thus, the top of the basement was calibrated with the top of the basalts (TB) of the Cabiunas Formation; the top of the Rift sequence with the Coqueiros Formation; the top of the Post-rift sequence with the pre-evaporite discordance (PED); the top of Salt with the Retiro Formation; the top of the Albian with the Outeiro Formation; the top of the Cenomanian-Maastrichtian sequence with the Tamoios Member (Ubatuba Formation); the top of the Paleocene-Oligocene sequence with the Siri Member (Emborê Formation), and the top of the Miocene-Pleistocene sequence with the Seabed (Fig. 4).

The seismic horizons of the 312 -D seismic lines were interpreted in two-way time (TWT), generating a grid of points for each interpreted horizon. 3-D surfaces were generated for each horizon by interpolation of data (Fig. 3) using the minimum curvature method. The polygon was delimited according to the highest density of seismic lines. Thus, two-way time surfaces were obtained for the top of the: Basement; Rift sequence; Post-rift sequence; Salt; Albian sequence; Cenomanian-Maastrichtian sequence; PaleoceneOligocene sequence; and the Miocene-Pleistocene sequence. The interpolation of stratigraphic horizons interpreted on seismic sections generated three-dimensional surfaces which, when projected on a map, revealed the structure of the packages.

The bottom surface interpolated for each sequence was subtracted from the top surface, in order to calculate the interval (in time) of each one. Using the mean velocity of each interval obtained from wells, the time intervals were converted into depth (in meters). These data were used to construct the isopach maps of the sedimentary packages: Rift sequence; Post-rift sequence; Salt; Albian sequence; Cenomanian-Maastrichtian sequence; PaleoceneOligocene sequence; and Miocene-Pleistocene sequence.

\section{Results}

\subsection{Structural analysis of surface data}

The Alegre Lineament is defined by valleys oriented predominantly N25 $5^{\circ}$, subparallel to the Colatina Lineament (Fig. 1). The aligned feature is identified from the eastern region of the Minas Gerais State to the extreme south of the Espírito Santo State, where it becomes undefined. In this region, we assumed that the Lineament shifts towards the east (Fig. 5a), which is inferred by the control that it exerts on the deposition of Cenozoic sediments (Fig. 5b). The coastline in the extreme northeast of the state of Rio de Janeiro is also parallel to this direction, and from there, the feature was inferred to the central portion of the Campos Basin. In Fig. 5c we did not trace the lineaments, in order to permit the reader to observe how the Alegre Lineament is clear and continuous in most of the area. In spite of the continuously of the main trace, a set of minor NNW-SSE lines also can be seen, sometimes forming clusters of lineaments that control the shape of drain channels.

The rosette diagram (Fig. 5a) shows the predominance of NNESSW (N25 ${ }^{\circ}$ E) and NE-SW (N45 $\left.{ }^{\circ} \mathrm{W}\right)$ lineaments, which correspond to the gneissic and mylonitic foliations, which have been studied previously (e.g. Pedrosa-Soares et al., 2011). In the NW-SE quadrant, a less marked set of lineaments appears ( $N 55^{\circ}$ to $\left.65^{\circ} \mathrm{W}\right)$, but the
Alegre set is the less frequent, showing that this feature is not a widespread structure and occurs along a narrow strip.

In the northern portion of the continental area, the Alegre Lineament reaches the Guaçuí Shear Zone (560-535 Ma; Alkmim et al., 2006) where becomes ill defined; but, passing this zone, the trace is clear again. This fact could indicate that the shear zone affect or displace the Alegre Lineament, but according to the field data that we show bellow, the studied structure is newer than the mylonitic zone.

When crossing the Santa Angelica Intrusive Complex (SAIC; $c a$. 520-480 Ma; Söllner et al., 2000), the Alegre Lineament pass between two gabbroic intrusions. This fact would imply that the lineament is a structure formed during the emplacement of these intrusions, but according to recent data of De Campos (2014), the magma segregation of this granitic complex was not affected by tectonic deformation. By the other hand, some sections of the Lineament coincides with the contact between units of the Neoproterozoic basement and Neoproterozoic granitoids, as indicated on Vieira's geological map (1997).

Four gabbroic dikes were identified along the Alegre Lineament (Fig. 5c), and are under study by the team of this work. The dikes called LA, IT, and JM have NW-SE to NNW-SSE strikes, subparallel to the Lineament, and the MU dike is oriented to NE-SW, following the foliation of the host rock. The dike thickness vary from 0.5 to $3.0 \mathrm{~m}$. Cooling fractures are remarkable in LA, JM, and MU dikes (Figs. 6a, b, and d), while the characteristics of IT refer to a deeper emplacement level (Fig. 6c). Mendes et al. (2014) analyzed some of these occurrences, identifying two groups of dikes: an alkaline and a tholeiitic one. The authors describe the existence of at least two dike generations, providing from different magmatic sources during different tectonic events.

Field measures along the whole area ( $40 \mathrm{~km}$ buffer) showed the regional foliation oriented to NE-SW, dipping towards SE (Fig. 7a). The gneissic foliation commonly has an intermediate dip angle,

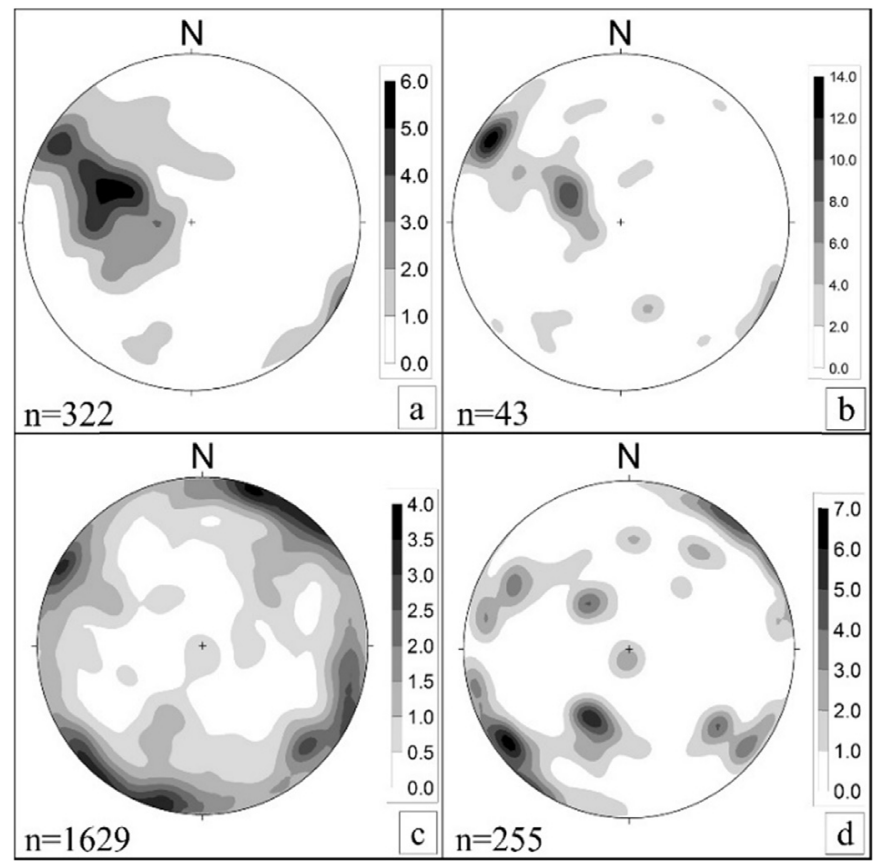

Fig. 7. Polar stereographic projections of ductile and brittle structures measured in the field, grouped in sets of 40 and 3-km buffers from the Alegre Lineament. (a) Gneissic and mylonitic foliation in the 40-km buffer, and (b) 3-km buffer; (c) joints in the 40-km buffer, and (d) 3-km buffer (low hemisphere projections in grid of equal area; $\mathrm{n}=$ number of data) 
while the mylonitic foliation occurs predominantly at a high dip angle, characterizing the shear zones such as Guaçuí and Batatal. When analyzed in the $3 \mathrm{~km}$ buffer, the foliations show the same pattern (Fig. 7b), and do not show any relation to the Alegre Lineament orientation.

Families of joints oriented to WNW-ESE and NW-SE are the most frequent in the $40 \mathrm{~km}$ buffer, with others oriented NE-SW and NNE-SSW (Fig. 7c). In the set of measurements taken in the $3 \mathrm{~km}$ buffer, the joints of the NE-SW quadrant become less representative and the high angle NW-SE family remains, with a WNW-ESE oriented group with intermediate dip angle towards NNE also present (Fig.7d).

Faults measured in the field affect weathered rocks of the crystalline basement, and some of them have striations imprinted on infill material composed by Fe and Mn oxy-hydroxides and clay minerals (Fig. 8). These faults occur concentrated in four different areas or structural domains (Fig. 8a). The area I is exactly on the trace of the Alegre Lineament (NNW-SSE), where most of the normal/oblique faults has the same orientation of this feature and just a few faults is oriented according to the gneissic foliation, which vary between NE-SW and NNE-SSW (Fig. 8b). The area II is on the Guaçuí Shear Zone and the faults have equal orientation to the mylonitic foliation (NNE-SSW) that marks this regional structure. In this area, we also found fault planes with striae marked on Mn oxide pellicle (Fig. 8c). The area III is near the Itapemirim River the main drainage channel of the region; and the area IV is located farther south, on the Além Paraíba shear zone. In the last two areas, oblique/normal faults affect the weathered gneissic basement in an ENE-WSW main trend (Fig. 8d and e).

The kinematic inversion of the fault dataset indicated, in the areas I, II, and III, an extensional stress field with the minor axis to NW-SE; and, in the area IV, the extensional axis is oriented to NESW (Fig. 9). The foliation's attitude is similar in all of them, varying between NNE-SSW and NE-SW. The joints more frequently occur in the areas I and II, where the Mn oxides commonly appear, indicating that these sites had a larger fracturing degree where the
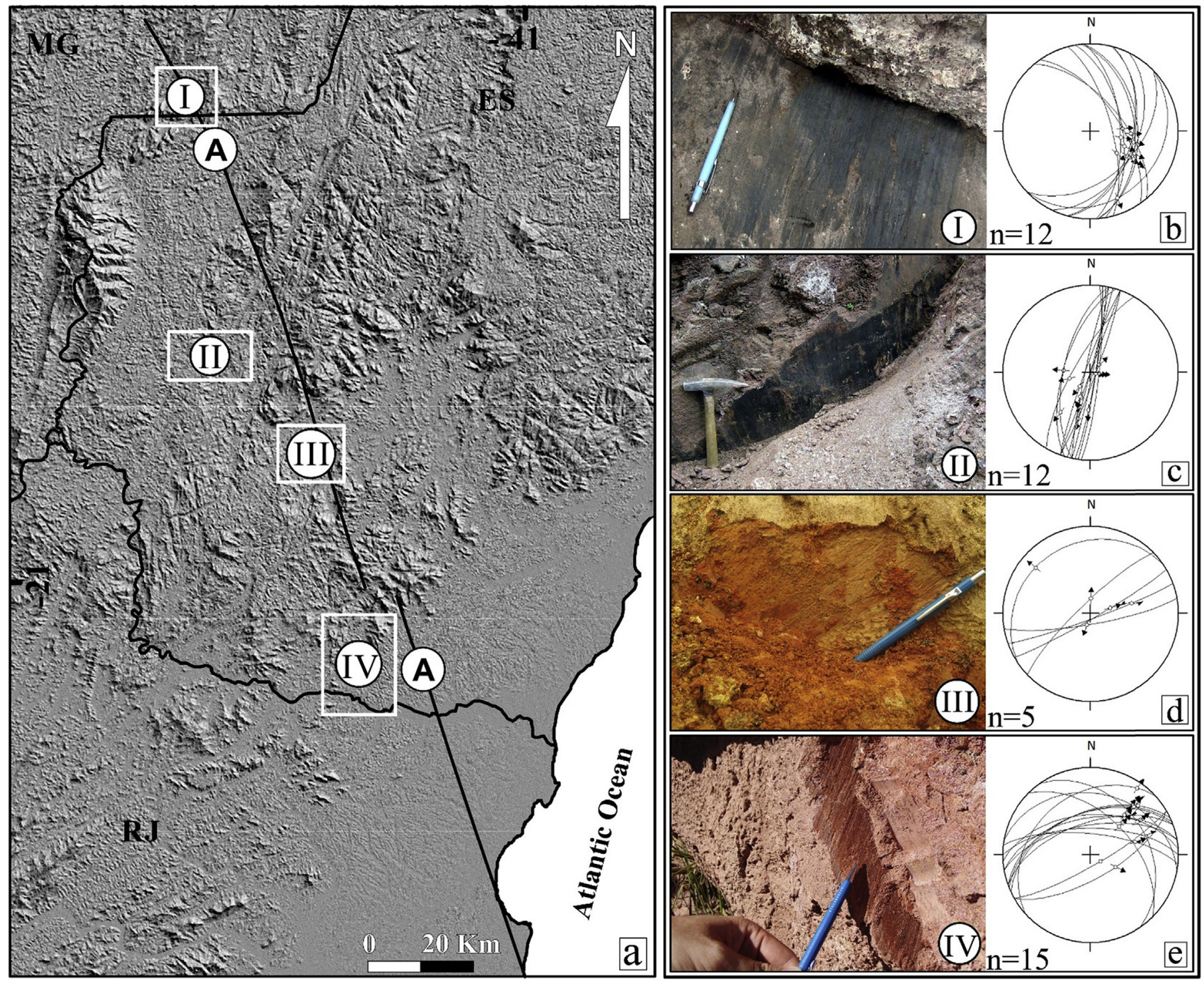

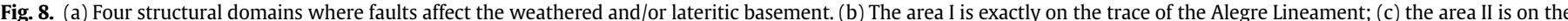

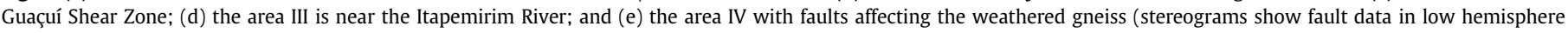
projection in grid of equal area; $n=$ number of data). 
rusty material filled the discontinuities before faulting.

\subsection{Structural analysis of the subsurface}

Two predominant structural styles were found: (i) normal faults that affect the Basement and the Rift sequence; and (ii) extensional structures generated mainly by overload of the stratigraphic sequence and salt tectonics that affect the upper sequences (halokinetics deformation).

Fig. 10 depicts the interpretation of three seismic sections perpendicular to the Alegre Lineament (strike sections; approximately NE-SW direction), positioned from the portion closest to the shoreline to the distal portion, close to the oceanic slope. Fig. 10a shows faults that delimit a structural high corresponding to the Badejo High, identified earlier by Guardado et al. (2000). Aeromagnetic data reported by Stanton et al. (2010) and Lourenço et al. (2014) show the alignment of a NNW-SSE trending negative magnetic anomaly separating the Badejo High from the Campos Magnetic High. Fig. 10b shows high-angle normal faults with apparent displacement in the section of the Alegre Lineament stretching toward the offshore area. These faults comprise a cluster along a stretch of $40 \mathrm{~km}$, controlling a structural low in the NE portion of the basin, which corresponds to the Corvina-Parati Low (Guardado et al., 2000, Fig. 10c). It is important to note that at certain sites in the continental area, the Alegre Lineament also appears in the form of a lineament cluster (Fig. 5c).

The occurrence of faults that appear to be linked to the Alegre Lineament is restricted to the proximal and central portions of the basin. However, this correlation cannot be made in the distal sections, as illustrated in Fig. 10c. On the other hand, in this distal section, a structural low appears on the NE side, indicating the action of NW-SE oriented structures, which can be interpreted as a transfer fault. Transfer faults are high dip faults that transfer the displacement between two normal faults, and are approximately parallel to the minor horizontal effort (Gibbs, 1984). They are part of the extensional system, working as a balancing mechanism in rifts with different rates of crustal stretching (Harding and Lowell, 1979; Milani, 1990).

The identification of transfer faults in seismic sections is based on elements that indicate strike-slip faulting, mainly due to the presence of flower structures (Zalán, 1986). Indications of strikeslip motion were sought in the interpretation of seismic sections, but of the 31 sections available, only three showed evidence of strike-slip motion. Fig. 10b illustrates a negative flower structure associated with basement faults, which occur in the same position as the transfer faults described in the literature (Cobbold et al., 2001; Meisling et al., 2001; Lourenço et al., 2014).

Most of faults that affect the Basement and the Rift sequence is observed in strike sections with apparent dip oriented to NE and in dip sections with apparent dip oriented to SE. The faults in the Basement and Rift sequence are intermediate to high-angle synthetic-antithetic faults with apparent normal displacement, which form horsts and grabens. Among the 218 faults that deform the Basement and Rift sequence, $20 \%$ also deform younger packages (Fig. 11a). In 14 of the 31 interpreted sections, we identified normal faults that affect the Rift sequence, with apparent normal displacement of about $40 \mathrm{~ms}-300 \mathrm{~ms}$ (milliseconds; TWT), and also affect the post-Rift sequence, but with displacement of $10 \mathrm{~ms}-200 \mathrm{~ms}$ (Fig. 11b). Such observations indicate the reactivation of structures formed during the rift phase.

Faults associated with halokinetic processes were identified in 13 of the 31 interpreted seismic sections. These faults, which affect the base salt level and continue as far as the Miocene-Pleistocene sedimentary unit, are predominantly synthetic faults (Fig. 11c). The halokinetic deformation are mostly visible in the strike sections with an apparent intermediate dip angle oriented to NE. In dip sections, these faults occur with apparent SE-oriented dip. Although the strike of these faults occurs in the same direction as

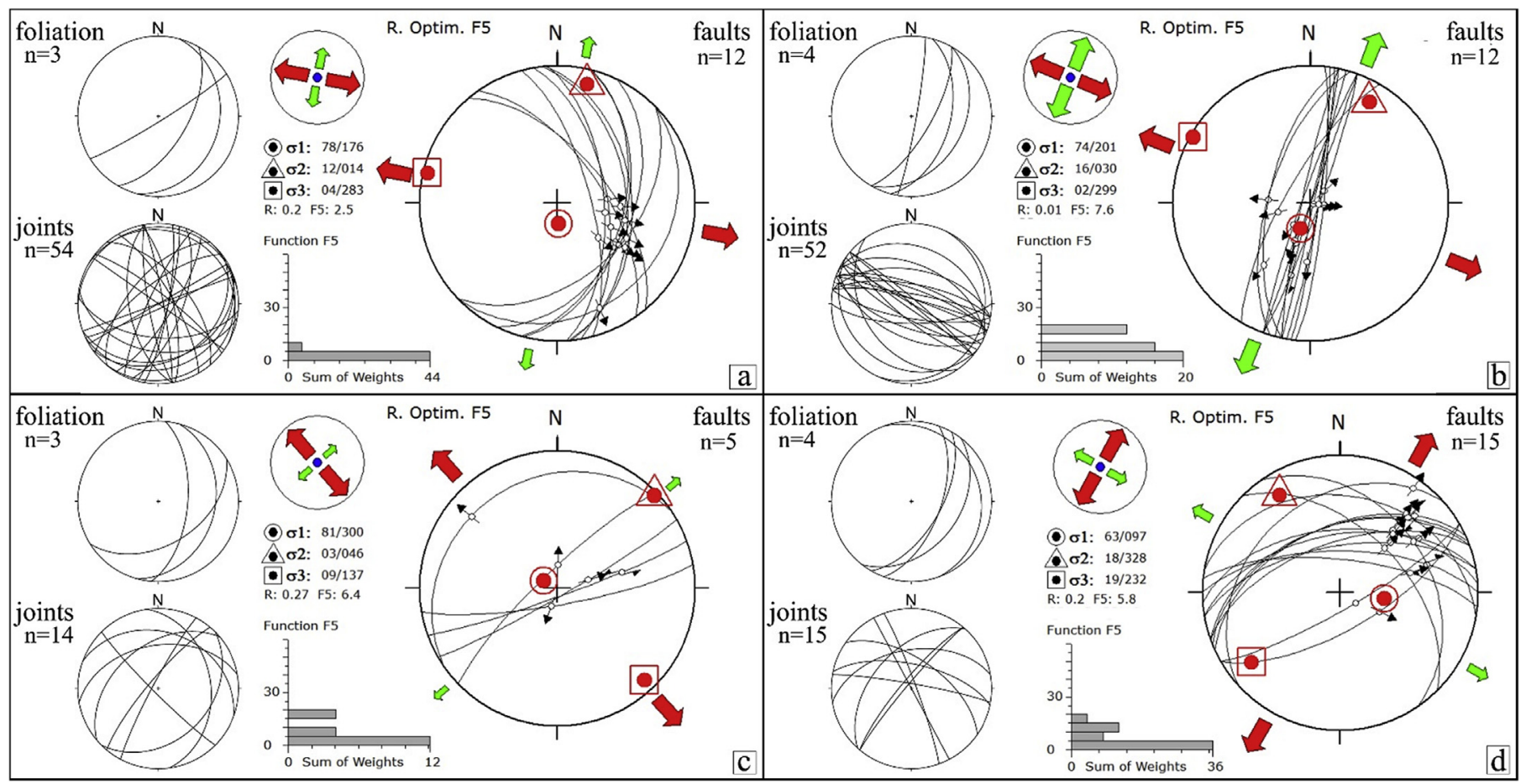

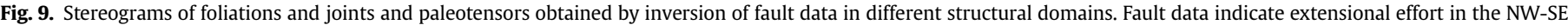

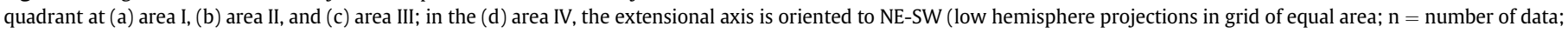
$\sigma 1=$ maximum, $\sigma 2=$ intermediate, and $\sigma 3=$ minimum tension axis). 
the rift phase faults, the processes whereby they are formed are related to eastward tilting of the basin and to differential sediment compaction after the period of tectonic quiescence (Guardado et al., 1989). However, movements related to the reactivation of rift phase structures associated with halokinetic faults may also occur.

Faults that affect only the upper sequences were also observed, with displacements up to $120 \mathrm{~ms}$ (Fig. 11a). These are gravitational faults formed in response to the weight of the sedimentary cover on mobile basal levels, as compensation for the sedimentary package.

The 3-D surfaces generated by interpolation of the interpreted horizons (Fig. 12) show an outstanding NE-SW structural control of the sedimentary surfaces, with more pronounced control in the region of the oceanic slope. The letter " $A$ " indicates the projection of the Alegre Lineament from the land to the basin. The maps of the top of the basement to the top of the Cenomanian-Maastrichtian sequence (Fig. 12h to c) show structural highs on the West side of the lineament and structural downs on the East side. The upper and lower portions are delineated by contours aligned in the NNW-SSE direction, parallel to the lineament. Note, also, the presence of inflections oriented to NW-SE, suggesting that such structures also control the geometry of the packages. Nevertheless, in the top of the sequences Paleocene-Oligocene and Miocene-Pleistocene (Fig. 12b and a), this pattern is not observed.

The isopach maps (Fig. 13) show the variations in sedimentary package thickness indicating depocenters developed since the rift phase. Although some influence of the seismic line positions had influenced in the isopachs outlines, it is possible to note that the distribution of depocenters is controlled by the NE-SW structural
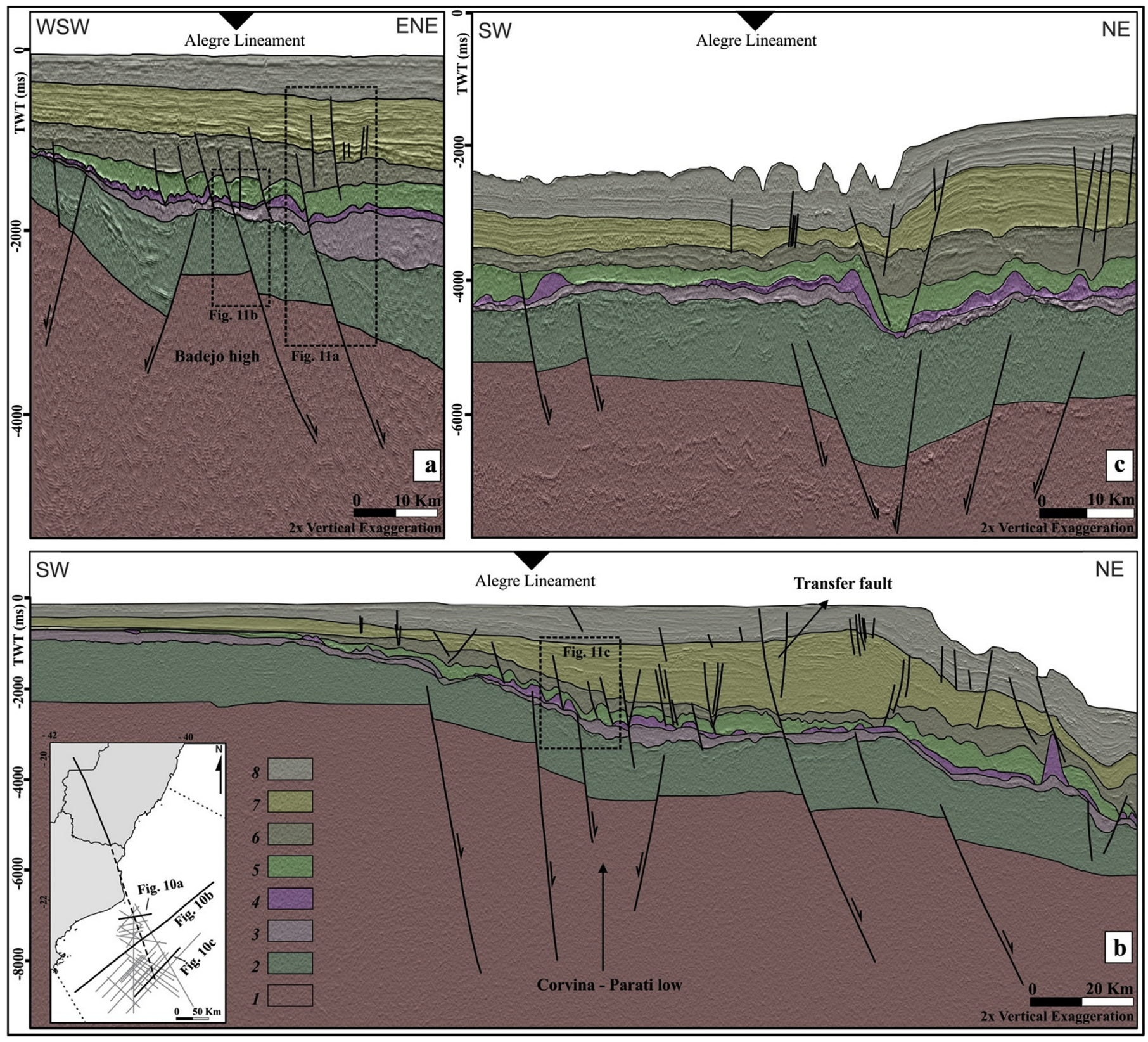

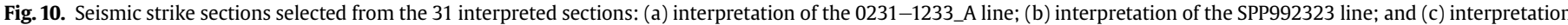

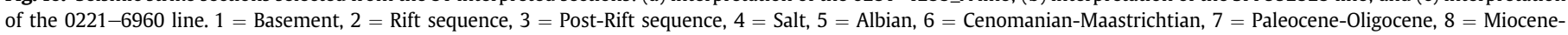
Pleistocene. 
trend. Another structural control is also observable in the Rift, PostRift and Salt sequences (Fig. 13g to e), that show thicker packages in the Easter side of the Alegre Lineament projection (dashed line). An attenuation of the tectonic control occurred during the deposition of the Albian and Maastrichtian-Cenomanian sequences (Fig. 13d and $\mathrm{c}$ ), when that structural feature seems to be inactive. The Paleocene-Oligocene sequence (Fig. 13b) shows the reactivation of the depocenter controlled by the Lineament, which seems to divide two tectonic domains into the basin. In the Miocene-Pleistocene sequence (Fig. 13a), the depression is completely filled and the accommodation space previously existing is no longer observed, shaping the seabed. Gravitational faults and residual halokinetic movements mark the structural stile of this phase.

The integration between the seismic profiles, the structural maps and the isopach maps enabled us to create a schematic panorama of the main structural elements in the central portion of the Campos Basin (Fig. 14). Most of the identified structures are NESW normal faults dipping toward SE, which delimit structural highs and lows. We also found NW-SE normal faults dipping to SW and NE (Fig. 14c). The trend NW-SE connects NE-SW fault planes, as well as, reverse dipping NE-SW faults (Fig. 14c). Thus, those NW-SE faults were considered transfer faults (dashed black lines), which can be associated with the transfer faults described by Cobbold et al. (2001), Meisling et al. (2001), Stanton et al. (2010) and Lourenço et al. (2014). Oliveira (2015) also identified NW-SE transfer faults (blue dashed lines) near the shoreline, which separate various segments of the Campos Fault compounding an echelon pattern.

In the central region of the study area, we identified NNW-SSE faults positioned on the projection of the Alegre Lineament (Fig. 14c). The NNW-SSE normal faults associated with the Alegre Lineament delimit the Corvina-Parati Low to ENE, with high blocks that give rise to the Cabo Frio High (Fig. 14c). The Corvina-Parati Low coincides in part with the Internal Depocenter of the Campos Basin identified by Fetter (2009). In addition, the NE-SW faults of the Cabo Frio High have terminations in trace of the Alegre lineament. Oliveira (2015) showed, besides the displacement of the Campos Fault along NW-SE structures, just one trace oriented to NNW-SSE near the shoreline, which coincides with the our outline of the Alegre Lineament at the same site (Fig. 14c). Also, note that the spatial arrangement of the Campo de Namorado reservoirs (Arienti et al., 1995) is restricted to the NE side of the area of action of the Alegre Lineament.

\section{Discussion}

The integration of the surface and subsurface data reveals that the Alegre Lineament is a set of geological structures that acted as joints and faults during the structural evolution of the Campos Basin and adjacent continental area. Then we will call, from here, this feature as the Alegre Fracture Zone (AFZ).

The continental field data show that, although the AFZ cut the ductile framework formed during the Brasiliano/Pan-African orogenic cycle, the outline of this brittle structure affect the contacts of some Neoproterozoic gneiss and granitic bodies. Viewed through remote sensing, it seems that the Guaçuí Shear Zone intercepts the AFZ outline, but the field data show that the last one is a brittle structure formed after the lateral scape of the orogeny, so after the ductile shear stage. The interaction between these features evidences reactivations of the mylonitic zone posteriorly to the formation of the Alegre structure. Then, we propose that the AFZ discontinuities originated as a set of joints in the Cambrian, in the final phase of the Brasiliano/Pan-African orogenic cycle.

We did not find any kinematic indicator that could show lateral motions along this structure in its origin. Nevertheless, the presence of basic dykes along the AFZ indicates that it was a very profound set of fractures or a weakness zone in the crust subjected to extensional stresses. In the northern region of the Espírito Santo State, similar dikes occur along the Colatina Lineament or Colatina Fracture Zone (CFZ; Belém, 2014). One of these bodies was dated as Jurassic in age (Silva et al., 1987) and its formation was associated with the basaltic overflow of the Cabiunas Formation into the Campos Basin (Valente et al., 2009; Novais et al., 2004). However, dating from zircon $(\mathrm{U}-\mathrm{Pb})$ performed in basic dikes subparallel to the CFZ attributed these intrusions to the Cambrian (Belém, 2014). The dikes of Southern Espírito Santo are currently being dated by the team of one of the authors of this paper. So far, what can be stated is that the presence of these dikes along the AFZ indicates that this belt was subjected to extensional stresses during more than one tectonic pulse.

In the Early Cretaceous, beginning of the Atlantic Ocean opening, the pre-existing NE-SW to NNE-SSW foliation worked as weakness zones that controlled the coastal basin development. In the Campos Basin, these structures were reactivated forming NE-
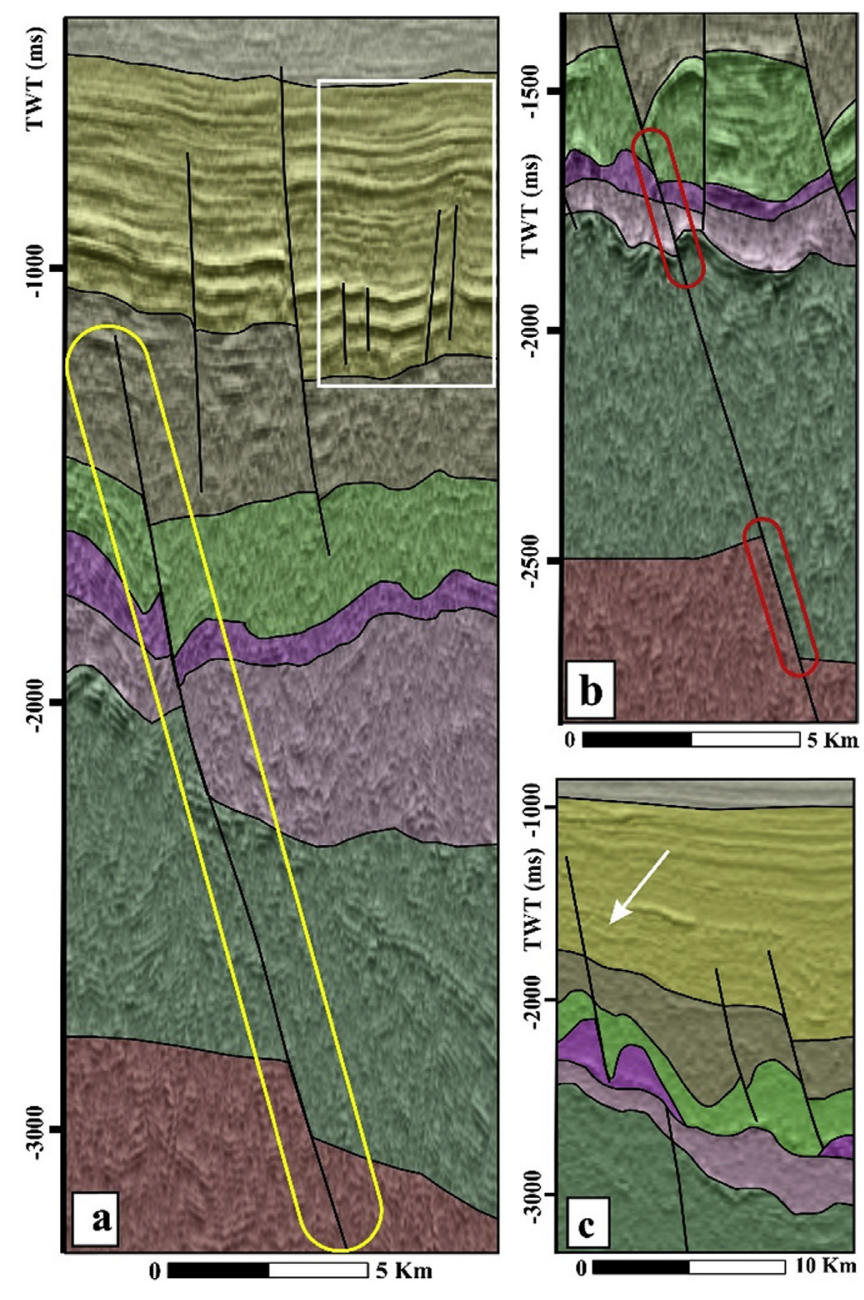

Fig. 11. Details of the stratigraphic and structural interpretation of the seismic lines. (a) Normal fault with apparent dip towards NE affects the Basement up to the Cenomanian-Maastrichtian sequence, with differential displacement (yellow polygon), and normal faults with apparent dip to NE affecting only the Paleocene-Oligocene sequence (white polygon). (b) Normal fault with apparent dip towards NE affecting the Basement with a displacement of $260 \mathrm{~ms}$ and the Rift, Post-rift and Salt sequences with displacement of up to $30 \mathrm{~ms}$ (red polygons). (c) Normal fault with apparent dip towards NE affecting the Salt layer (white arrow). (For interpretation of the references to colour in this figure legend, the reader is referred to the web version of this article.) 


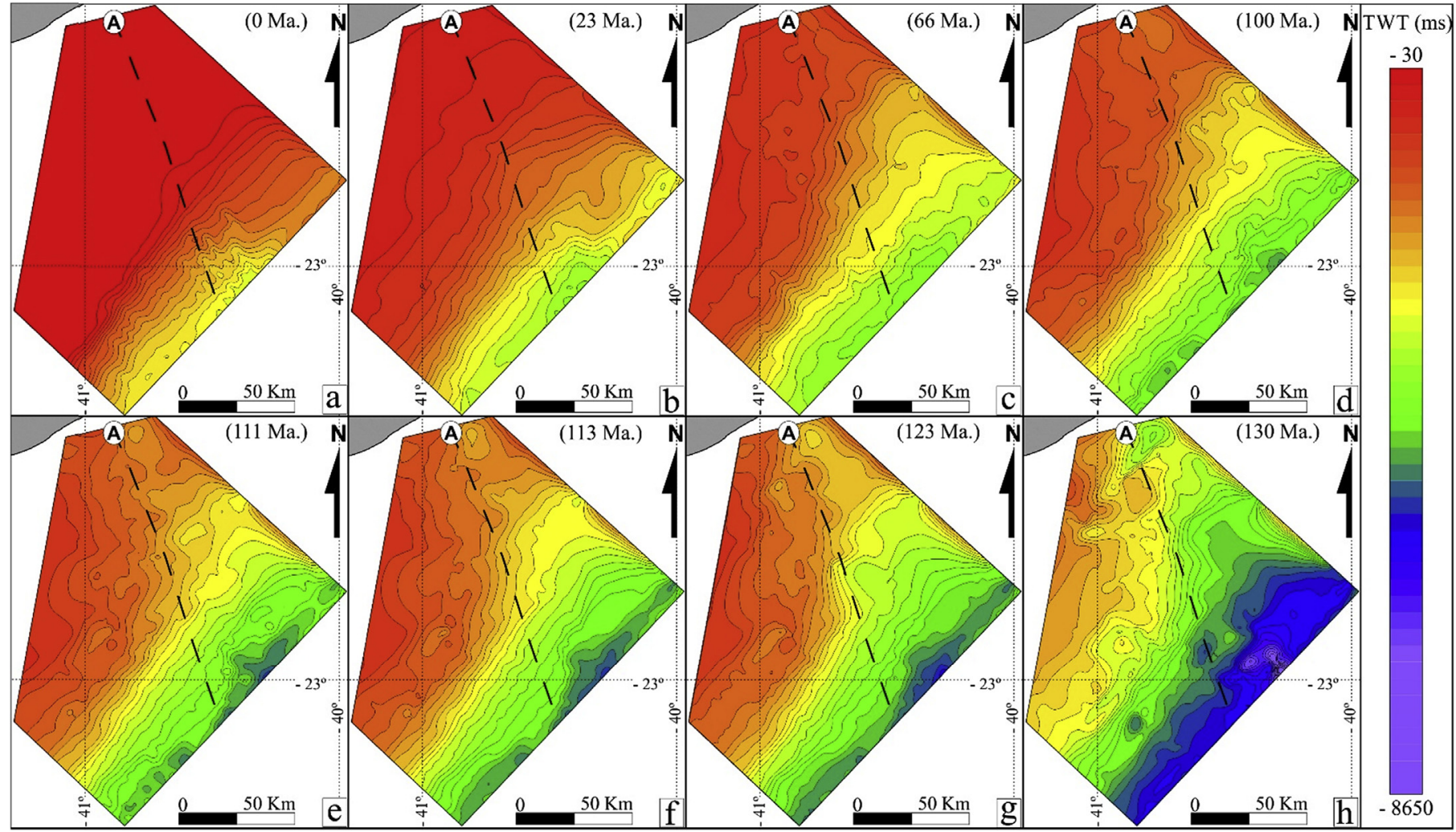

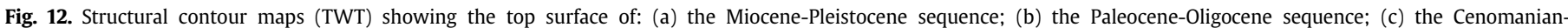
Maastrichtian sequence; (d) the Albian sequence; (e) the Salt; (f) the Post-rift sequence; $(\mathrm{g})$ the Rift sequence and (h) the Basement. (A = projection of Alegre Lineament).

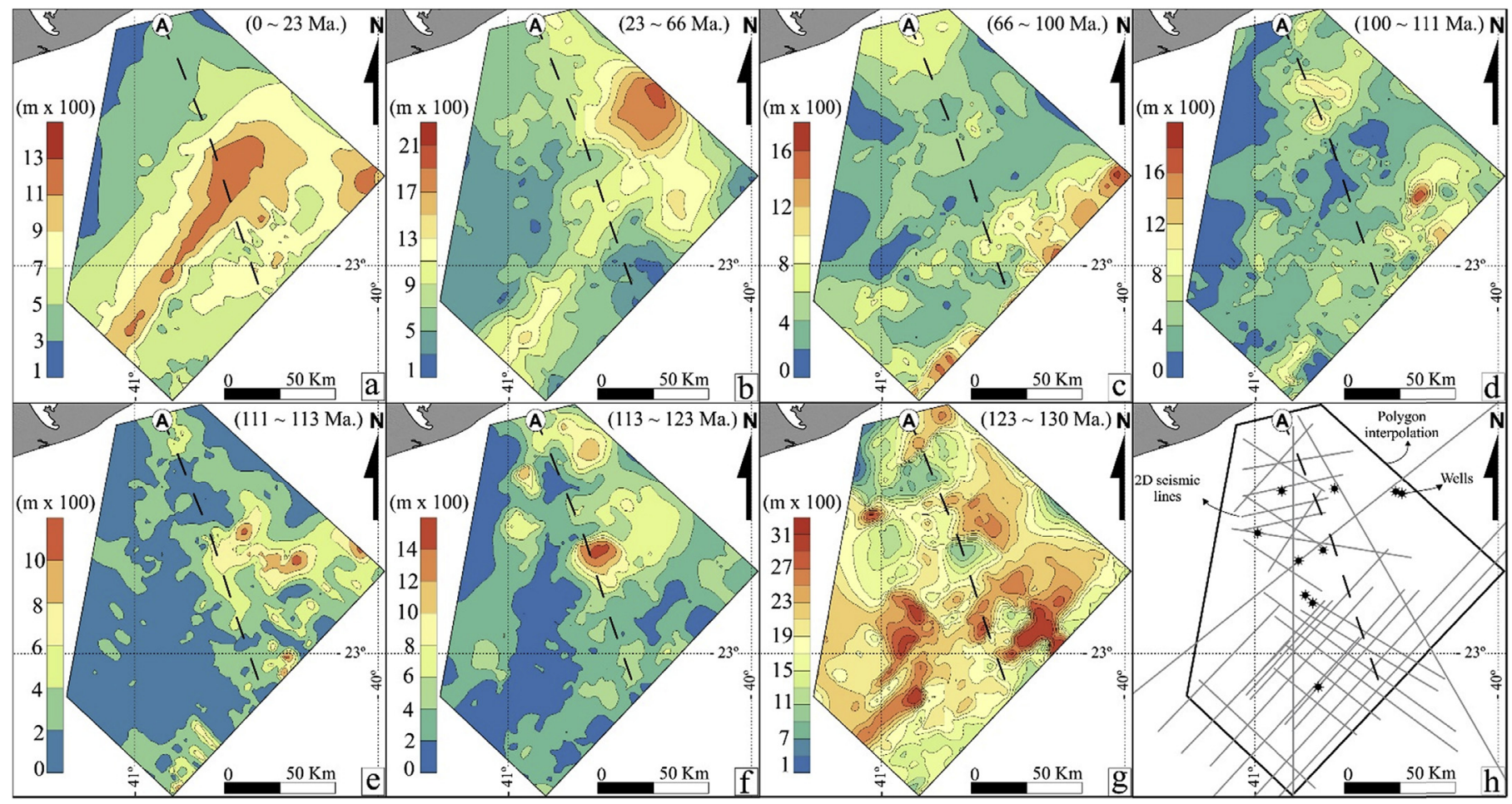

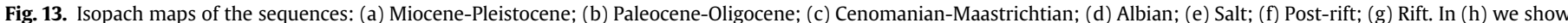
the location of the seismic lines and wells used for interpolating data. (A = projection of Alegre Lineament).

SW normal faults, in response to the generally NW-SE extensional processes of the rift phase as described by various authors (e.g.,
Schaller, 1973; Dias et al., 1987, 1990; Guardado et al., 1989; Chang et al., 1992; Stanton et al., 2010). The configuration observed in the 
offshore structural map (Fig. 14) results from a normal fault system that produced NE-SW elongated grabens, controlled by the main structures of the Precambrian basement. This NE-SW control was also important during the Cenozoic, which is highlighted by Schaller (1973) who describes onshore NE-SW normal faults delimiting deposits of the Barreiras Formation and Quaternary sediments of the Campos Basin, obliquely segmented by NW-SE striking faults.

The NW-SE faults mapped in our work (Fig. 14) are considered transfer faults, in agreement with Cobbold et al. (2001), Meisling et al. (2001), Stanton et al. (2010) and Lourenço et al. (2014). A set of NW-SE transfer faults affects the Campos Fault and dislocates the NE-SW trace in various stepped segments (Oliveira, 2015). These faults, originated also in the Early Cretaceous, transect the passive margin obliquely and control the main depocenters of the Barremian sedimentary unit, which are responsible for most of the oil accumulations in the Campos Basin (Meisling et al., 2001; Guardado et al., 1989). In this phase, the AFZ acted as NNW-SSE normal faults in part of the Campos Basin, controlling the establishment of the Corvina-Parati Low, where the NNW-SSE faults comprises a complex system together with the NE-SW fault set and the NW-SE transfer faults. In addition to the NW-SE transfer faults, the AFZ also dislocate the Campos Fault along the shoreline in the
North of Rio de Janeiro State (Fig. 14).

In the continental area, we did not encounter temporal markers indicating how the behavior of the AFZ was during the rift phase. The majority of the observed faults affect the weathered basement or some lateritic material that we consider newer than the strong uplift that occurred in the region after the rift phase as related by some authors (e.g. Jelinek et al., 2014; Cogné et al., 2012). The increase in thickness observed in the Paleocene-Oligocene sequence of the Campos Basin (Fig. 13b) reflects this uplifting, which probably affected a large area of SE Brazil, culminating in intense erosion of the continental area and significant increase in the input of sediments to the adjacent marginal basins (Hackspacher et al., 2004; Hiruma et al., 2010).

The faults registered in the onshore area, affecting the weathered and/or lateritic filling material, indicate reactivation of preexisting structures. Probably, the preexisting discontinuities belonging to the AFZ assimilated the tectonic movements and reactivated the fracture planes as NNW-SSE normal faults. The same concept can be used to explain the brittle structural pattern that we found in the Guaçuí Shear Zone, where weathered and lateritic material over NNE-SSW discontinuities shows fault striations. Various researchers highlighted the important role of older structure reactivations in the NE and SE Brazilian continental

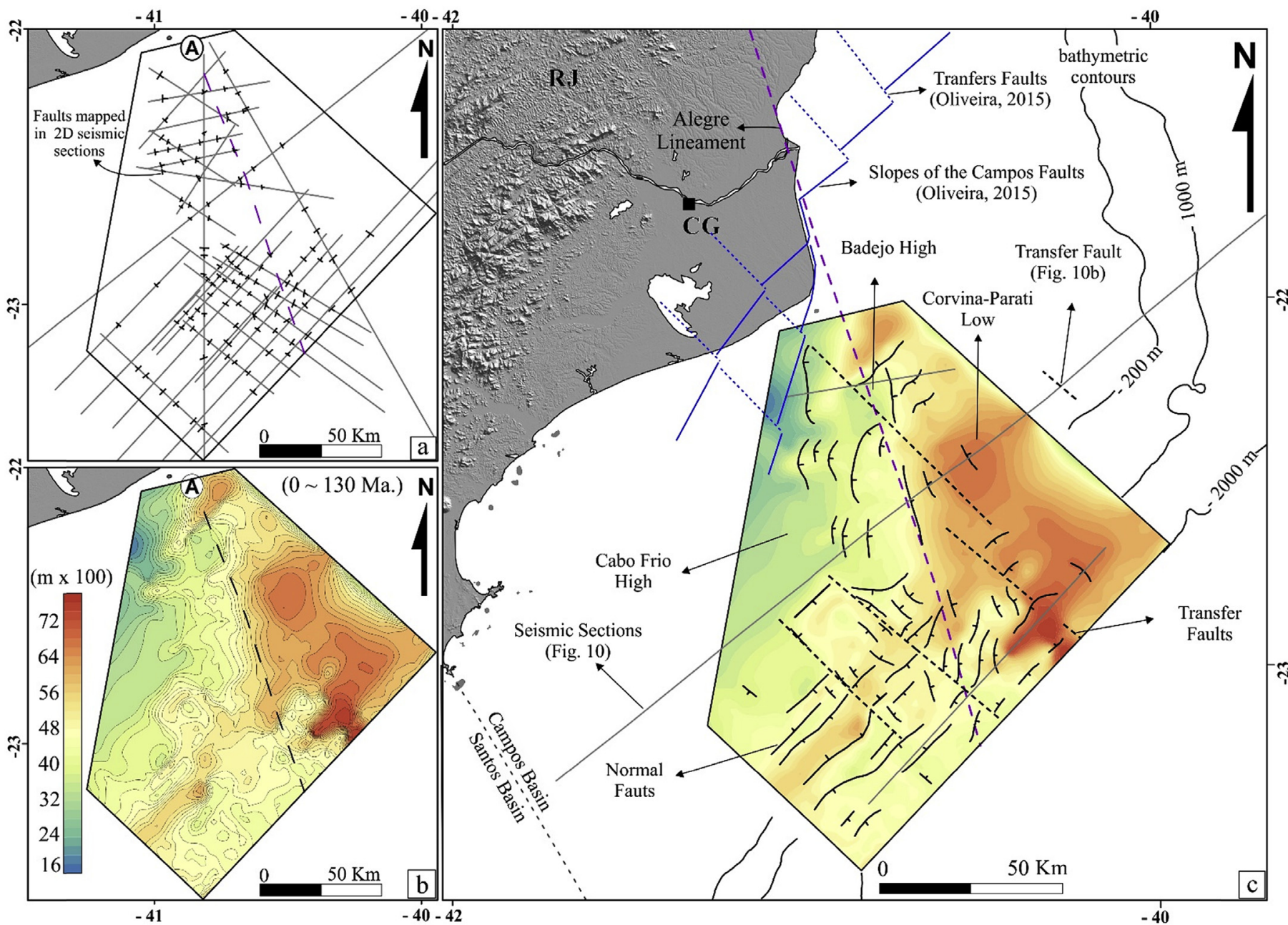

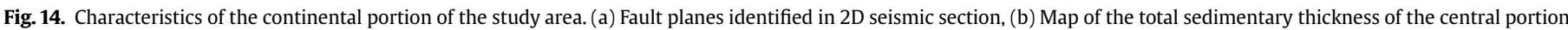

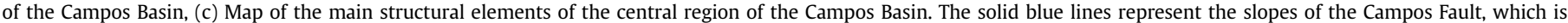

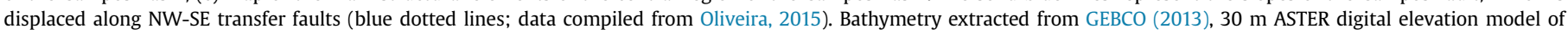
ERSDAC (2013). (For interpretation of the references to colour in this figure legend, the reader is referred to the web version of this article.). 
margin (e.g. Bezerra and Vita-Finzi, 2000; Bezerra et al., 2014; Cogné et al., 2012; Gontijo-Pascutti et al., 2010). Then, we consider that the faults whose analysis generated the paleotensors showed in Fig. 9 are young faults, dating from the Neogene or less.

Although the data fault indicate, in the areas I, II and III, a NW-SE distensional event (Figs. 9a, b, and c), it is possible that this local state of stress is a consequence of a different tensor arrangement acting regionally. According to previous researchers (Riccomini et al., 1989; Salvador and Riccomini, 1995; Silva and Mello, 2011), a sinistral transcurrent and a NW-SE distensional tectonic event acted in the SE Brazil, respectively, in the Neogene and Quaternary. Both of them have the minor tension axis in the NW-SE quadrant and such state of stress could generate the set of faults that we observed onshore. In spite of the local arrangement of faults encountered in the area IV (Fig. 9d) indicates a NE-SW distension, these structures are compatible with the dextral strike-slip tensor that acted in the Pleistocene according to some authors (Riccomini et al., 1989; Salvador and Riccomini, 1995; Silva and Mello, 2011). Another possibility is that these faults were generated by the gravitational collapse proposed by Zalán and Oliveira (2005), which would generate a sinistral transtension with the minor axis oriented to NW-SE between 58 and 20 Ma.

Analyzing these findings carefully, it is necessary to point out the observation of Bezerra and Vita-Finzi (2000) who, studying reactivated structures in NE-Brazil, affirm that the maximum horizontal axis recovered from reactivated structures can be quite different of the paleotensor acting regionally. Therefore, observing the structural data of continental area, we can only affirm that, from the Neogene, the AFZ was activated as a set of normal faults, subjected to a local tension relief.

\section{Conclusions}

Based on the structural analysis performed in this study, allied to the information available in the literature, we concluded that:

a The Alegre Lineament reflects a regional fault, that we named here as the AFZ. This geological structure acted both onshore and offshore, along an almost continuous line of approximately $250 \mathrm{~km}$ in length.

b Onshore, the AFZ is identified as a set of NNW-SSE oriented fractures formed by extensional effort in the Early Cambrian, which were reactivated as normal faults during the Cenozoic, probably in the Neogene and Quaternary. We did not find temporal markers indicating how the behavior of the AFZ was during the rift phase.

c Offshore, the NNW-SSE fault system associated with the Alegre Lineament acted in the generation of the Corvina-Parati Low during the rift phase up to the final Aptian, with reactivations in the Paleocene. This system comprises a complex arrangement of faults with the NW-SE transfer faults and the NE-SW faults.

\section{Acknowledgments}

We acknowledge CAPES (Brazil's Federal Agency for the Support and Improvement of Higher Education) for the scholarship granted to the first author, FINEP (Brazil's Research and Projects Financing Agency) for its financial aid to cover the fieldwork (under Agreement No. 01.10.0808.00), and the National Petroleum Agency (ANP) for providing the 2-D seismic sections and well logs. We are also grateful to Prof. Francisco Hilário Bezerra, Giulio Viola and the third anonymous reviser of SAMES, who greatly contributed to the improvement of this work.

\section{Appendix A. Supplementary data}

Supplementary data related to this article can be found at http:// dx.doi.org/10.1016/j.jsames.2016.04.005.

\section{References}

Alkmim, F.F., Marshak, S., Pedrosa-Soares, A.C., Peres, G.G., Cruz, S.C.P., Whittington, A., 2006. Kinematic evolution of the Araçuaí-West Congo orogen in Brazil and Africa: nutcracker tectonics during the neoproterozoic assembly of Gondwana. Precambrian Res. 149, 43-64. http://dx.doi.org/10.1016/ j.precamres.2006.06.007.

Alkmim, F.F., Pedrosa-Soares, A.C., Noce, C.M., Cruz, S.C.P., 2007. Sobre a evolução tectônica do Orógeno Araçuaí-Congo Ocidental. Geonomos 15 (1), 25-43.

Almeida, F.F.M., Brito Neves, B.B., Fuck, R., 1981. Brazilian structural provinces: an introduction. Earth Sci. Rev. 17, 1-29. http://dx.doi.org/10.1016/0012-8252(81) 90003-9.

Almeida, F.F.M., Carneiro, C.D.R., 1998. Origem e evolução da Serra do Mar. Rev. Bras. Geociênc. 28 (2), 135-150.

Arienti, L.M., Backheuser, Y., Abreu, C.J., Cândido, A., 1995. Estratigrafia e modelo deposicional do Arenito Namorado do Campo de Albacora, Bacia de Campos. Bol. Geociênc. Petrobras 9 (2/4), 249-263.

BDEP, 2013. Banco de Dados de Exploração e Produção. Disponível em. http://www bdep.gov.br (accessed 05.04.13.).

Belém, J., 2014. Geoquímica, geocronologia e contexto geotectônico do magmatismo máfico associado ao Feixe de Fraturas Colatina, Estado do Espírito Santo. PhD Thesis. Instituto de Geociências, Universidade de Minas Gerais, p. 134.

Bezerra, F.H.R., Rossetti, D.F., Oliveira, R.G., Medeiros, W.E., Brito Neves, B.B., Balsamo, F., Nogueira, F.C.C., Dantas, E.L., Andrades Filho, C., Góes, A.M., 2014. Neotectonic reactivation of shear zones and implications for faulting style and geometry in the continental margin of NE Brazil. Tectonophysics 614, 78-90. http://dx.doi.org/10.1016/j.tecto.2013.12.021.

Bezerra, F.H.R., Vita-Finzi, C., 2000. How active is a passive margin? Paleoseismicity in Northeastern Brasil. Geology 28, 591-594 doi:10.1130/0091-7613(2000) $28<591$ :HAIAPM $>2.0$. CO; 2 .

Brito Neves, B.B., 2002. Main stages of the development of the Sedimentary Basins of South America and their relationship with the Tectonics of Supercontinents Gondwana Res. 5, 175-196. http://dx.doi.org/10.1016/j.tecto.2013.12.021.

Cainelli, C., Mohriak, W.U., 1999. Some remarks on the evolution of sedimentary basins along the Eastern Brazilian continental margin. Episodes 22, 206-216.

Chang, H.K., Kowsmann, R.O., Figueiredo, A.M.F., Bender, A., 1992. Tectonics and stratigraphy of the East Brazil Rift system: an overview. Tectonophysics 213, 97-138. http://dx.doi.org/10.1016/0040-1951(92)90253-3.

Cobbold, P.R., Meisling, K.R., Mount, V.S., 2001. Reactivation of an obliquely-rifted margin, Campos and Santos basins, Southeastern Brazil. Am. Assoc. Pet. Geol. Bull. 85, 1925-1944 doi:10.1306/8626D0B3-173B-11D7-8645000102C1865D.

Cobbold, P.R., Rossello, E.A., Roperch, P., Arriagada, C., Gómez, L.A., Lima, C., 2007. Distribution, Timing, and Causes of Andean Deformation across South America. In: Geological Society, London, Special Publications, 272, pp. 321-343. http:// dx.doi.org/10.1144/GSL.SP.2007.272.01.17.

Cogné, N., Gallagher, K., Cobbold, P.C., Riccomini, C., Gautheron, C., 2012. Postbreakup tectonics in southeast Brazil from thermochronological data and combined inverse-forward thermal history modeling. J. Geophys. Res 117 (B11). B11413. http://dx.doi.org/10.1029/2012JB009340.

Cogné, N., Cobbold, P.R., Riccomini, C., Gallagher, K., 2013. Tectonic setting of the Taubaté Basin (Southeastern Brazil): Insights from regional seismic profiles and outcrop data. J. South Am. Earth Sci 42, 194-204. http://dx.doi.org/10.1016/j. jsames.2012.09.011.

Cunningham, D., Alkmim, F.F., Marshak, S., 1998. A structural transect across the coastal mobile belt in the Brazilian Highlands (latitude $20^{\circ} \mathrm{S}$ ): the roots of a Precambrian transpressional orogen. Precambrian Res. 92, 251-275. http:// dx.doi.org/10.1016/S0301-9268(98)00077-1.

Davison, I., 1997. Wide and narrow margins of the Brazilian South Atlantic. J. Geol. Soc. Lond. 154, 471-476. http://dx.doi.org/10.1144/gsjgs.154.3.0471.

De Campos, C.P., 2014. Chaotic flow patterns from a Deep Plutonic Environment: a Case study on Natural magma Mixing. Pure Appl. Geophys. 172, 1815-1833. http://dx.doi.org/10.1007/s00024-014-0940-6.

De Campos, C.M., Mendes, J.C., Ludka, I.P., Medeiros, S.R., Moura, J.C., Wallfass, C., 2004. A review of the Brasiliano magmatism in southern Espírito Santo, Brazil, with emphasis on post-collisional magmatism. J. Virtual Explor. 17, 1-35. http:// dx.doi.org/10.3809/jvirtex.2004.00106.

Delvaux, D., Sperner, B., 2003. Stress tensor inversion from fault kinematic indicators and focal mechanism data: the TENSOR program. In: Nieuwland, D.A (Ed.), New Insights into Structural Interpretation and Modelling, Special Publication of the Geological Society of London, 212, pp. 75-100.

Dias, J.F., Guazelli, W., Catto, A.J., Vieira, J.C., 1987. Integração do arcabouço estrutural da Bacia de Campos com o embasamento Pré-Cambriano adjacente. In: I Simpósio de Geologia Regional RJ-ES. Anais, Rio de Janeiro, pp. 189-197.

Dias, J., Scarton, J., Esteves, F., Carminatti, M., Guardado, L., Lincoln, R., 1990 Aspectos da evolução tectono-sedimentar e a ocorrência de hidrocarbonetos na Bacia de Campos. In: Gabaglia, G.P.R., Milani, E.J. (Eds.), Origem e Evolução de Bacias Sedimentares. Petrobras, pp. 333-360.

ERSDAC, 2013. Earth Remote Sensing Data Analysis Center (ASTER GDEM). http:// 
gdem.ersdac.jspacesystems.or.jp (accessed 10.09.13.).

Fetter, M., 2009. The role of basement tectonic reactivation on the structural evolution of Campos Basin, offshore Brazil: evidence from 3D seismic analysis and section restoration. Mar. Pet. Geol. 26, 873-886. http://dx.doi.org/10.1016/ j.marpetgeo.2008.06.005.

Fodor, R.V., McKee, E.H., Asmus, H.E., 1983. K-Ar ages and the opening of the south Atlantic ocean: basaltic rock from the Brazilian margin. Mar. Geol. 54 (1-2), M1-M8. http://dx.doi.org/10.1016/0025-3227(83)90002-6.

GEBCO, 2013. General Bathymetric Chart of the Oceans. http://www.gebco.net/ (accessed 15.06.13.).

Gibbs, A.D., 1984. Structural evolution of extensional basin margins. J. Geol. Soc. Lond. 141, 609-620. http://dx.doi.org/10.1144/gsjgs.141.4.0609.

Gontijo-Pascutti, A., Bezerra, F.H.R., La Terra, E., Almeida, J.C.H., 2010. Brittle reactivation of mylonitic fabric and the origin of the Cenozoic Rio Santana Graben, southeastern Brazil. J. S. Am. Earth Sci. 29, 522-536. http://dx.doi.org/10.1016/ j.jsames.2009.06.007.

Gradim, C., Roncato, J., Pedrosa-Soares, A.C., Cordani, U., Dussin, I., Alkmin, F.F., Queiroga, G., Jacobson, T., Da Silva, L.C., Babinski, M., 2014. The hot back-arc zone of the Araçuaí orogen, Eastern Brazil: from sedimentation to granite generation. Braz. J. Geol. 44 (1), 155-180. http://dx.doi.org/10.5327/Z2317 4889201400010012.

Grohmann, C.H., Campanha, G.A.C., Soares Junior, A.V., 2011. OpenStereo: um programa Livre e multiplataforma para análise de dados estruturais. In: XII Simpósio Nacional de Estudos Tectônicos.

Guardado, L.R., Gamboa, L.A.P., Luchesi, C.F., 1989. Petroleum geology of the Campos Basin, a model for a producing Atlantic-type basin. In: Edwards, J.D. Santogrossi, P.A. (Eds.), Divergent/Passive Margin Basins, Am. Assoc. Pet. Geol. Bull., 48, pp. 3-79.

Guardado, L.R., Spadini, A.R., Brandão, J.S.L., Mello, M.R., 2000. Petroleum system of the Campos Basin, Brazil. In: Mello, M.R., Katz, B.J. (Eds.), Petroleum Systems of South Atlantic Margins, Am. Assoc. Pet. Geol. Mem., 73, pp. 317-324.

Hackspacher, P.C., Ribeiro, L.F.B., Ribeiro, M.C.S., Fetter, A.H., Hadler Neto, J.C.S. Tello, C.E.S., Dantas, E.L., 2004. Consolidation and break-up of the South American platform in southeastern Brazil: tectonothermal and denudation histories. Gondwana Res. 1, 91-101. http://dx.doi.org/10.1016/S1342-937X(05) 70308-7.

Harding, T.P., Lowell, J.D. 1979. Structural styles, their plate tectonic habitats, and hydrocarbon traps in petroleum provinces. Assoc. Pet. Geol. Bull. 63 (7) 1016-1058.

Hasui, Y., 1990. Neotectônica e aspectos fundamentais da tectônica ressurgente no Brasil. In: Workshop sobre neotectônica e sedimentação cenozoica continenta no Sudeste brasileiro. Anais, Belo Horizonte, pp. 1-31.

Heilbron, M., Moriak, W., Valeriano, C., Almeida, J.C.H., Tupinambá, M., 2000. From collision to extension: the roots of the southeastern continental margin of Brazil. In: Mohriak, W., Tankard, M. (Eds.), Atlantic Rifts and Continental Margins, Geophys. Monogr., 115. American Geophysical Union, pp. 1-32. http:// dx.doi.org/10.1029/GM115p0001.

Heilbron, M., Pedrosa-Soares, A.C., Campos Neto, M. Silva, L.C., Trouw, R.A.J. Janasi, V.C., 2004. A Província Mantiqueira. In: Mantesso-Neto, V., Bartorelli, A Carneiro, C.D.R., Brito Neves, B.B. (Eds.), O Desvendar de um Continente: A Moderna Geologia da América do Sul e o Legado da Obra de Fernando Flávio Marques de Almeida, 13. Editora Beca, São Paulo, pp. 203-234.

Heilbron, M., Tupinambá, M., Valeriano, C.M., Armstrong, R., Siva, L.G.E., Melo, R.S. Simonnetti, A., Pedrosa-Soares, A.C., Machado, N., 2013. The Serra da Bolivia complex: the record of a new Neoproterozoic arc-related unit at Ribeira belt Precambrian Res. 238, 158-175. http://dx.doi.org/10.1016/ j.precamres.2013.09.014.

Hiruma, S.T., Riccomini, C., Modenesi-Gauttieri, M.C., Hackspacher, P.C., Hadle Neto, J.C., Franco-Magalhães, A.O.B., 2010. Denudation history of the Bocaina Plateau, Serra do Mar, southeastern Brazil: relationships to Gondwana breakup and passive margin development. Gondwana Res. 18, 674-687. http: dx.doi.org/10.1016/j.gr.2010.03.001.

IEMA, 2007. Instituto Estadual de Meio Ambiente e Recursos Hídricos. In: Levantamento Aerofotogramétrico na escala 1:35000. http://www.meioambiente.es. gov.br. Accessed 10 August 2011.

Jelinek, A.R., Chemale Jr., F., Van der Beek, P.A., Guadagnin, F., Cupertino, J.A., Viana, A., 2014. Denudation history and landscape evolution of the Northern East-Brazilian continental margin from apatite fission-track thermochronology. J. S. Am. Earth Sci. 54, 158-181. http://dx.doi.org/10.1016/j.jsames.2014.06.001.

Karl, M., Glasmacher, U.A., Kollenz, S., Franco-Magalhaes, A.O.B., Stockli, D.F. Hackspacher, P.C., 2013. Evolution of the South Atlantic passive continental margin in southern Brazil derived from zircon and apatite (U-Th-Sm)/He and fission-track data. Tectonophysics 604, 224-244. http://dx.doi.org/10.1016/j. tecto.2013.06.017.

Lourenço, J., Menezes, P.T.L., Barbosa, V.C.F., 2014. Connecting onshore-offshore Campos basin structures: interpretation of high-resolution airborne magnetic data. Interpretation 2 (4), 181-191. http://dx.doi.org/10.1190/int-2014-0007.1.

Meisling, K.E., Cobbold, P.R., Mount, V.S., 2001. Segmentation of an obliquely rifted margin, Campos and Santos basins, Southeastern Brazil. Am. Assoc. Pet. Geol. Bull. 85, 1903-1924.

Mendes, R.S., Neves, M.A., Medeiros Junior, E.B., Rangel, C.V.G.T., 2014. Ocorrências de diques máficos no sul do Estado do Espírito Santo. In: 47 Congresso Brasileiro de Geologia. anais, Salvador.

Michon, L., Sokoutis, D., 2005. Interaction between structural inheritance and extension direction during graben and depocenter formation: an experimental approach. Tectonophysics 409, 125-146. http://dx.doi.org/10.1016/ j.tecto.2005.08.020.

Milani, E.J., 1990. Estilo estruturais em bacias sedimentares - revisão conceitual. In: Gabalia, G.P.R., Milani, E.J. (Eds.), Origem e Evolução de Bacias Sedimentares. Petrobrás, pp. 75-96.

Milani, E.J., Brandão, J.A.S.L., Zalán, P.V. Gamboa, LA.P., 2000. Petróleo na margem continental brasileira: geologia, exploração, resultados e perspectivas. Braz. J. Geophys. 18, 351-396.

Mizusaki, A.M.P., Thomaz Filho, A., Valença, J.G., 1988. Volcano-sedimentary sequence of Neocomian age in Campos Basin (Brazil). Rev. Bras. Geociênc. 18, $247-251$.

Mohriak, W.U., 2003. Bacias Sedimentares da Margem Continental Brasileira. In: Bizzi, L.A., Schobbenhaus, C., Vidotti, R.M., Gonçalves, J.H. (Eds.), Geologia, Tectônica e Recursos Minerais do Brasil, 3. CPRM, Brasília, pp. 87-165.

Mohriak, W.U., 2012. Bacias de Santos, Campos e Espírito Santo. In: Hasui, Y., Carneiro, C.D.R., Almeida, F.F.M., Bartorelli, A. (Eds.), Geologia Do Brasil, 19b. Editora Beca, São Paulo, pp. 481-496.

Mohriak, W.U., Mello, M.R., Dewey, J.F., Maxwell, J.R., 1990. Petroleum geology of the Campos basin, offshore Brazil. In: Brooks, J. (Ed.), Classic Petroleum Provinces, Special Publication of the Geological Society of London, 50, pp. 119-141. http:// dx.doi.org/10.1144/gsl.sp.1990.050.01.07.

Novais, L.C.C., Teixeira, L.B., Neves, M.T., Rodarte, J.B.M., Almeida, J.C.H., Valeriano, C.M., 2004. Novas ocorrências de diques de diabásio na faixa Colatina ES: estruturas rúpteis associadas e implicações tectônicas para as bacias de Campos e do Espírito Santo. Bol. Geociênc. Petrobrás 12, 191-194.

Ojeda, H.A.O., 1982. Structural framework, stratigraphy, and evolution of Brazilian Marginal Basins. Am. Assoc. Pet. Geol. Bull. 66, 732-749.

Oliveira, J.P.M., 2015. Caracterização sismoestrutural do embasamento do Complexo Deltaico do Rio Paraíba do Sul. Ms Dissertation. Instituto de Geociências, Universidade Federal do Rio de Janeiro, p. 125.

Pedrosa-Soares, A.C., De Campos, C. Noce, C.M., Silva, L.C., Novo, T., Roncato, J., Medeiros, S., Castañeda, C., Queiroga, G., Dantas, E., Dussin, I., Alkmim, F.F., 2011. Late Neoproterozoic-cambrian Granitic Magmatism in the Araçuai orogen (Brazil), the Eastern Brazilian Pegmatite Province and Related Mineral Resources. In: Special Publication of the Geological Society of London, 350, pp. $25-51$.

Pedrosa-Soares, A.C., Noce, C.M., Alkmim, F.F., Silva, L.C., Babinski, M., Cordani, U., Castañeda, C., 2007. Orógeno Araçuaí: síntese do conhecimento 30 anos após Almeida 1977. Geonomos 15 (1), 1-16.

Pedrosa-Soares, A.C., Noce, C.M., Wiedemann, C.M., Pinto, C.P., 2001. The Araçuaí West-Congo Orogen in Brazil: an overview of a confined orogen formed during Gondwana land assembly. Precambrian Res. 110, 307-323.

Pedrosa-Soares, A.C., Wiedemann-Leonardos, C.M., 2000. Evolution of the Araçuaí Belt and its connection to the Ribeira Belt, Eastern Brazil. In: Cordani, U., Milani, E.J., Thomaz-Filho, A., Campos, D.A. (Eds.), Tectonic Evolution of South America. Sociedade Brasileira de Geologia, São Paulo, pp. 265-285.

Ponte, F.C., Asmus, H.E., 1978. Geological framework of the Brazilian continental margin. Geol. Rundsch. 67, 201-235.

Rangel, H.D., Martins, F.A.L., Esteves, F.R., Feijó, F.J., 1994. Bacia de Campos. Bol. Geociênc. Petrobras 8, 203-217.

Renne, P.R., Ernesto, M., Pacca, I.G., Coe, R.S., Glen, J.M., Prévot, M., Perrin, M., 1992 The age of Paraná flood volcanism, rifting of Gondwanaland, and the JurassicCretaceous boundary. Science 258, 975-979. http://dx.doi.org/10.1126/ science.258.5084.975.

Riccomini, C., Peloggia, A., Saloni, J., Kohnke, M., Figueira, R., 1989. Neotectonic activity in the Serra do Mar rift system (southeastern Brazil). J. S. Am. Earth Sci. 2, 191-197. http://dx.doi.org/10.1016/0895-9811(89)90046-1.

Rossetti, D.F., Bezerra, F.H.R., Dominguez, J.M.L., 2013. Late Oligocene-Miocene transgressions along the equatorial and eastern margins of Brazil. Earth Sci. Rev. 123, 87-112. http://dx.doi.org/10.1016/j.earscirev.2013.04.005.

Salomon, E., Koehn, D., Passchier, C., Hackspacher, P.C., Glasmacher, U.A., 2015. Contrasting stress fields on correlating margins of the South Atlantic. Gondwana Res 28 (3), 1152-1167. http://dx.doi.org/10.1016/j.gr.2014.09.006.

Salvador, E.D., Riccomini, C., 1995. Neotectônica da região do Alto Estrutural de Queluz (SP-RJ, Brasil). Rev. Bras. Geociênc. 25, 151-164.

Schaller, H., 1973. Estratigrafia da Bacia de Campos. In: $27^{\circ}$ Congresso Brasileiro de Geologia, 3. Anais, Aracajú, pp. 247-258.

Silva, J.N., 1993. Programa Levantamentos Geológicos Básicos do Brasil. Cachoeiro de Itapemirim. Folha SF.24-V-A-V. In: Estado do Espírito Santo. Escala 1:100.000. DNPM/CPRM, Brasília, p. 165.

Silva, J.M.R., Lima, M.I.C., Veronese, V.F., Ribeiro Jr., R.N., Rocha, R.M., Siga Jr., O., 1987. Geologia. In: Projeto RADAMBRASIL - Folha SE 24 Rio Doce: geologia, geomorfologia, pedologia, vegetação, uso potential da terra, 34. Departamento Nacional da Produção Mineral (DNPM), Rio de Janeiro, 1v. +6 mapas.

Silva, M.A., Camozzato, E., Paes, V.J.C., Junqueira, P.A., Ramgrab, G.E., 2004. Folha SF.24-Vitoria. In: Schobbenhaus, C., Goncalves, J.H., Santos, J.O.S., Abram, M.B., Leão Neto, R., Matos, G.M.M., Vidotti, R.M., Ramos, M.A.B., Jesus, J.D.A. de (Eds.), Carta Geológica do Brasil ao Milionésimo, Sistema de Informações Geográficas. Programa Geologia do Brasil. CPRM, Brasília (CD-ROM).

Silva, T.P., Mello, C.L., 2011. Reativações Neotectônicas na Zona de Cisalhamento do Rio Paraíba do Sul (Sudeste do Brasil). Geologia USP. Série Científ. 11 (1), 95-111.

Söllner, F., Lammerer, B., Wiedemann, C.M., 2000. Dating the Ribeira Mobile Belt of Brazil. Sonderh. Z. für Angew. Geol. 245-255.

Stampfli, G.M., Hochard, C., Vérard, C., Wilhem, C., VonRaumer, J., 2013. The formation of Pangea. Tectonophysics 593, 1-19. http://dx.doi.org/10.1016/ 
j.tecto.2013.02.037.

Stanton, N., Schmitt, R.S., Galdeano, A., Maia, M., Mane, M., 2010. Crustal structure of the southeastern Brazilian Margin from aeromagnetic data: new kinematic constraints. Tectonophysics 490, 15-27. http://dx.doi.org/10.1016/ j.tecto.2010.04.008.

Szatmari, P., 2012. Rifting by continental rotation, mantle flow and hotspot volcanism in the salt-depositing South Atlantic. Geophys. Res. Abstr. 14, 11400.

Thomaz Filho, A., Cesero, P., Mizusaki, A.M., Leão, J.G., 2005. Hot spot volcanic tracks and their implications for South American plate motion, Campos basin (Rio de Janeiro state), Brazil. J. S. Am. Earth Sci. 18, 383-389.

Torsvik, T.H., Cocks, L.R.M., 2013. Gondwana from top to base in space and time. Gondwana Res. 24, 999-1030. http://dx.doi.org/10.1016/j.tecto.2010.04.008.

Trompette, R., Egydio-Silva, M., Tommasi, A., Vauchez, A., Uhlein, A., 1993. Amalgamação do Gondwana Ocidental no Panafricano-Brasiliano e o papel da geometria do cráton do São Francisco na arquitetura da faixa Ribeira. Rev. Bras. Geociênc. 23, 187-193.

Valente, S.C., Dutra, T., Heilbron, M., Corval, A., Szatmari, P., 2009. Litogeoquímica de Diques de Diabásio da Faixa de Colatina, ES. Geochim. Bras. 23, 177-192.

Veevers, J.J., 2004. Gondwanaland from 650-500 Ma assembly through 320 Ma merger in Pangea to 185-100 Ma breakup: supercontinental tectonics via stratigraphy and radiometric dating. Earth Sci. Rev. 68, 1-132. http://dx.doi.org/ 10.1016/j.earscirev.2004.05.002.

Vieira, V.S., 1997. Programa Levantamentos Geológicos Básicos do Brasil - Folha Cachoeiro de Itapemirim. Folha SF.24-V-A. In: Estado do Espírito Santo. Escala 1: 250.000. DNPM/CPRM, p. 110. Brasília.
Vieira, V.S., Silva, M.A., Corrêa, T.R., Lopes, M.H.B., 2014. Mapa Geológico do Espírito Santo - Escala 1:400.000. In: VI Simexmin - Simpósio Brasileiro de Exploração Mineral, Ouro Preto.

Viola, G., Kounov, A., Andreoli, M.A.G., Mattila, J., 2012. Brittle tectonic evolution along the western margin of South Africa: more than $500 \mathrm{Myr}$ of continued reactivation. Tectonophysics 514-517, 93-114. http://dx.doi.org/10.1016/j.tecto. 2011.10.009.

Wiedemann, C.M., Campos, C.M., Medeiros, S.R., Mendes, J.C., Ludka, I.P., Moura, J.C., 2002. Architecture of Late orogenic Plutons in the Araçuaí-Ribeira Folded Belt, Southeast Brazil. Gondwana Res. 19, 381-399. http://dx.doi.org/10.1016/S1342937X(05)70730-9.

Wilson, R.W., 2005. Basement control on faulting patterns, transtension and structural segmentation of the Lofoten Ridge, Norwegian Margin: using digital mapping to link onshore and offshore geology. Midl. Val. Prize 1-20.

Wilson, R.W., McCaffrey, K.J.W., Holdsworth, R.E., Imber, J., Jones, R.R., Welbon, A.I.F. Roberts, D., 2006. Complex fault patterns, transtension and structural segmentation of the Lofoten Ridge, Norwegian margin: using digital mapping to link onshore and offshore geology. Tectonics 25, TC4018. http://dx.doi.org/ 10.1029/2005TC001895.

Winter, W.R., Jahnert, R.J., França, A.B., 2007. Bacia de Campos. Bol. Geociênc. Petrobras 15 (2), 511-529.

Zalán, P.V., 1986. Identificação de falhas transcorrentes em seções sísmicas. Rev. Bras. Geociênc. 16 (3), 258-265.

Zalán, P.V., Oliveira, J.A.B., 2005. Origem e evolução estrutural do Sistema de Riftes Cenozóicos do Sudeste do Brasil. Bol. Geociênc. Petrobras 13 (2), 269-300. 